DEC 191996 ENGINEERING DATA TRANSMITTAL

Pago 1 of

1. EDT 161638

\begin{tabular}{|c|c|c|c|c|c|c|c|c|}
\hline \multicolumn{3}{|c|}{$\begin{array}{l}\text { 2. To: (Receiving Organization) } \\
\text { WRAP } 1\end{array}$} & \multicolumn{2}{|c|}{$\begin{array}{l}\text { 3. From: (originating Organization) } \\
\text { WRAP 1 }\end{array}$} & \multicolumn{4}{|c|}{$\begin{array}{r}\text { 4. Related EDT No.: } \\
\text { N/A }\end{array}$} \\
\hline \multicolumn{3}{|c|}{$\begin{array}{l}\text { 5. Proj./Prog./Dept./Div.: } \\
\text { W026/Solid Waste } \\
\text { Construction }\end{array}$} & \multicolumn{2}{|c|}{$\begin{array}{l}\text { 6. Design Authority/ Design Agent/Cog. } \\
\text { Engr.: } \\
\text { TL Watson }\end{array}$} & \multicolumn{4}{|c|}{$\begin{array}{l}\text { 7. Purchase Order No.: } \\
\qquad N / A\end{array}$} \\
\hline \multirow{2}{*}{\multicolumn{5}{|c|}{$\begin{array}{l}\text { 8. Originator Remarks: } \\
\text { For release }\end{array}$}} & \multicolumn{4}{|c|}{$\begin{array}{l}\text { 9. Equip./Component No.: } \\
\text { N/A }\end{array}$} \\
\hline & & & & & \multicolumn{4}{|c|}{$\begin{array}{l}\text { 10. System/Bldg./Facility: } \\
N / A\end{array}$} \\
\hline \multirow{3}{*}{\multicolumn{3}{|c|}{ 11. Receiver Remarks: }} & \multirow{3}{*}{\multicolumn{2}{|c|}{ eline Document? [] Yes $[X]$ No }} & \multicolumn{4}{|c|}{$\begin{array}{l}\text { 12. Major Assm. Dwg. No.: } \\
\text { N/A }\end{array}$} \\
\hline & & & & & \multicolumn{4}{|c|}{$\begin{array}{l}\text { 13. Permit/Permit Application No.: } \\
\text { N/A }\end{array}$} \\
\hline & & & & & \multicolumn{4}{|c|}{$\begin{array}{l}\text { 14. Required Response Date: } \\
\text { N/A }\end{array}$} \\
\hline \multicolumn{2}{|l|}{15.} & \multicolumn{3}{|c|}{ DATA IRANSMITIED } & (F) & (G) & (H) & (1) \\
\hline $\begin{array}{l}\text { (A) } \\
\text { Item } \\
\text { No. }\end{array}$ & (B) Document/Drawing No. & $\begin{array}{l}\text { (C) } \\
\text { Sheot } \\
\text { No. }\end{array}$ & $\begin{array}{l}\text { (D) } \\
\text { Rov. } \\
\text { No. }\end{array}$ & $\begin{array}{l}\text { (E) Title or Description of Data } \\
\text { Transmitted }\end{array}$ & $\begin{array}{l}\text { Approval } \\
\text { Desig- } \\
\text { nator }\end{array}$ & $\begin{array}{l}\text { Reason } \\
\text { for } \\
\text { Trans- } \\
\text { mittal }\end{array}$ & $\begin{array}{l}\text { Origi- } \\
\text { nator } \\
\text { Dispo- } \\
\text { sition }\end{array}$ & $\begin{array}{l}\text { Recoiv- } \\
\text { er } \\
\text { Dispo- } \\
\text { sition }\end{array}$ \\
\hline 1 & HAFF-SD-W026-ATP-016 & & 0 & HVAC Control System Test Plan & $Q$ & 2 & 1 & \\
\hline$\Rightarrow 2$ & NNF-SD-W026-ATR-016 & & 0 & $\begin{array}{l}\text { HVAC Control System Jest } \\
\text { Report }\end{array}$ & $Q$ & 2 & 1 & \\
\hline & & & & & & & & \\
\hline & & & & & & & & \\
\hline & & & & & & & & \\
\hline
\end{tabular}

\begin{tabular}{|c|c|c|c|c|}
\hline \multicolumn{5}{|c|}{16.} \\
\hline Approval Designator $(F)$ & & Reason for Transmittal [G] & Dispo & ion (H) \& (I) \\
\hline $\begin{array}{l}\text { E, S, Q, D or N/A } \\
\text { (see WHC-CM-3-5, } \\
\text { Sec.12.7) }\end{array}$ & $\begin{array}{l}\text { 1. Approval } \\
\text { 2. Release } \\
\text { 3. Information }\end{array}$ & $\begin{array}{l}\text { 4. Roviow } \\
\text { 5. Post-Review } \\
\text { 6. Dist. (Receipt Acknow. Required) }\end{array}$ & $\begin{array}{l}\text { 1. Approved } \\
\text { 2. Approved w/comment } \\
\text { 3. Disapproved w/comment }\end{array}$ & $\begin{array}{l}\text { 4. Reviewed no/comment } \\
\text { 5. Reviowed w/comment } \\
\text { 6. Receipt acknowledged }\end{array}$ \\
\hline
\end{tabular}

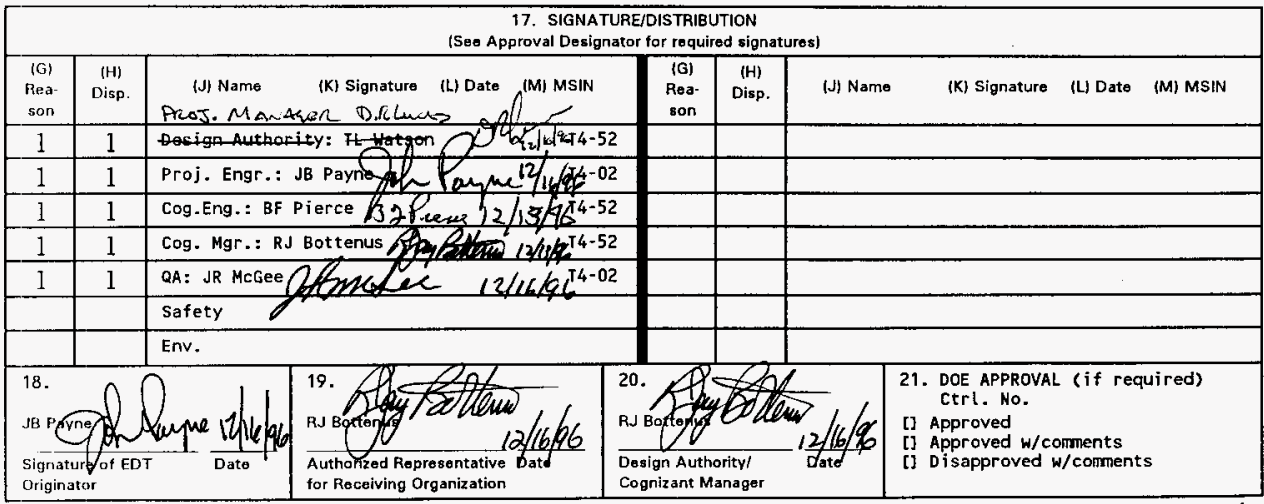

$B D+7400-172-2(05 / 96)$ GEF097 
HNF-SD-W026-ATR-016, Rev. 0

\section{W-026, Acceptance Test Report HVAC Control System (Submittal \# 1572.1)}

\section{TL Watson}

Westinghouse Hanford, Richland, WA 99352

U.S. Department of Energy Contract DE-AC06-87RL10930

EDT/ECN: EDT-16/638 UC:

Org Code: 04E00 Charge Code: P1JF18

B\&R Code: 39EW3130020 Total Pages: 70

Key Words: DCS, WRAP 1, ATR, Heating, Ventilation, Air Conditioning

Abstract: This report verified the HVAC-DSC performed to the criteria stated in this functional test.

TRADEMARK DISCLAIMER. Reference herein to any specific comercial product, process, or service by trade name, trademark, manufacturer, or otherwise, does not necessarily constitute or imply its endorsement, recominendation, or favoring by the United States Government or any agency thereof or its contractors or subcontractors.

Printed in the United States of America. To obtain copies of this document, contact: WHC/BCS Document Control Services, P.O. Box 1970, Mailstop H6-08, Richland WA 99352, Phone (509) 372-2420; Fax (509) 376-4989.
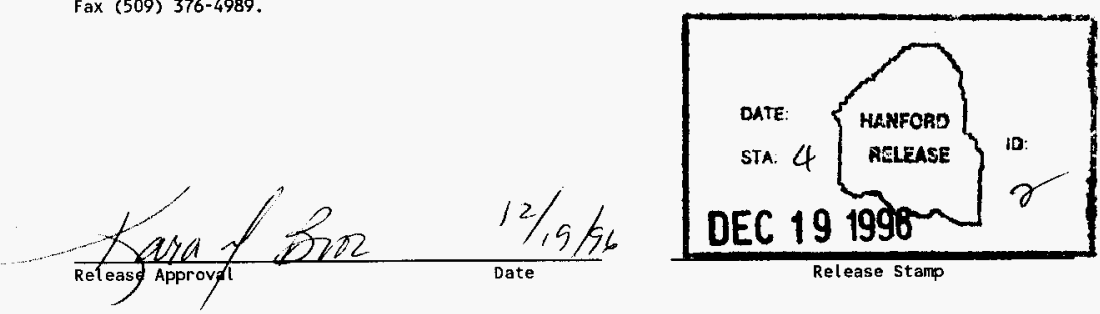

Release Stamp

\section{Approved for Public Release}


ATP (Y/N) Y

Test: Table $1 \mathrm{~A}$

Step:

Spec. Section:

Test Operator: $M$ att Harper

Test Witness/Author: Keith Ealden
ATP\#: HVAC Control ATP

Equipment Tag \#: 11-PDISL-622/623
Exception: 1

Revision: 0

Execution:

Date: 26 September 1996

Time: $1000 \mathrm{hrs}$

Responsible Contractor: PCL

Responsible Subcontractor: Building Control Services

Responsible Individual: Matt Harper

EXCEPTION DESCRIPTION: (Expected Result versus Actual Resuli)

Actuation of 11-PDISL-623 and 11-PDISL-624 should have resulted in tripping Supply Fan SF-11-101 and Return Fan RF-11-101 respectively, and the annunciation of the associated fan fail indication. Neither fan tripped and it was approximately 30 minutes before the Return Fan fail indication was received.

\section{EXCEPTION RESOLUTION:}

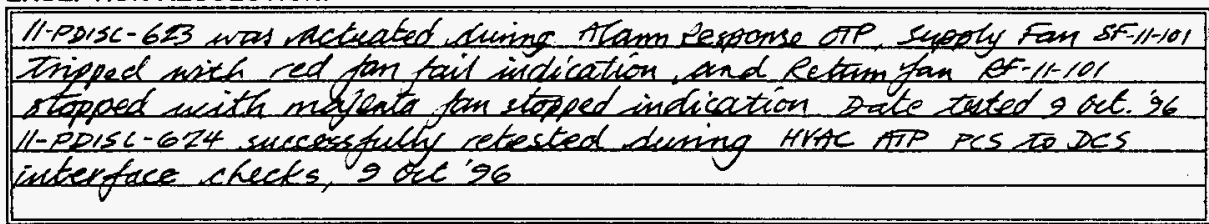

Exception Closed By:

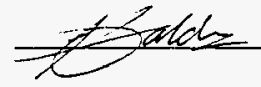

Date: 12 at's6.

\section{APPROVAL OF RESOLUTION}

Contractor Representative:

WHC Projects Representative:

WHC NFS Representative:

(NFS = New Facility Startup)

ICF KEH Representative:

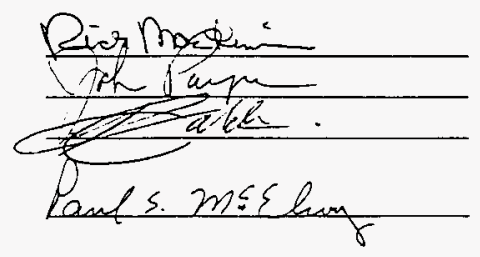

Date: $10 / 16 / 96$

Date: $10 / 16 / 96$

Date: 16 0if 96 .

Date: $10 / 16 / 96$. 


\section{WRAP ACCEPTANCE TEST PROCEDURE EXCEPTION LOG}

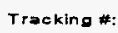

ATP $(Y / N) Y$

Test: Table $1 \mathrm{~B}$

Step: $1 . Z .1$

Spec. Section:

Test Operator: $M$ att Harper

Test Witness/Author: Keith Ealden
Exception: 2

Revision: 0

Execution:

Date: 26 September 1996

Time: $1410 \mathrm{hrs}$

Responsible Contractor: PCL

Responsible Subcontractor: Building Control Services

Responsible Individual: Matt Harper

EXCEPTION DESCRIPTION: (Expected Result versus Actual Result)

"Manual over-ride to un-occupied cycle" command issued at the PCS RTAP screen. Command was

received by the HVAC DCS system but no change in equipment status was noted.

Similar results were obtained when the "Manual over-ride to occupied cycle" command was issued at the

PCS RTAP screen.

\section{EXCEPTION RESOLUTION:}

\begin{tabular}{|l|}
\hline \\
\hline \\
\hline \\
\hline
\end{tabular}

Exception Closed By:

Date:

\section{APPROVAL OF RESOLUTION}

Contractor Representative:

Date:

WHC Projects Representative:

WHC NFS Representative:

Date:

(NFS = New Facility Startup)

Date:

ICF KEH Representative:

Date: 
WRAP ACCEPTANCE TEST PROCEDURE EXCEPTION LOG

ATP (Y/N) $Y$

ATP\#: HVAC Control ATP

Test: Table 1C

Step: 1.Z, 1

Equipment Tag \#: 11-XA-621

Spec. Section:

Test Operator: $M$ att Harper

Test Witness/Author: Keith Ealden
Exception: 3

Revision: 0

Execution:

Date: 26 September 1996

Time: 1030hrs

Responsible Contractor: PCL

Responsible Subcontractor: Building Control Services

Responsible individual: Matt Harper

EXCEPTION DESCRIPTION: (Expected Result versus Actual Result)

\begin{tabular}{|l|}
\hline Controller C-11-101 "Trouble" condition was simulated but alarm was not received at the PCS. \\
\hline \\
\hline
\end{tabular}

EXCEPTION RESOLUTION:

\begin{tabular}{|l|l|}
\hline Seec. \\
\hline \\
\hline \\
\hline
\end{tabular}

Exception Closed By:

Date:

\section{APPROVAL OF RESOLUTION}

Contractor Representative:

WHC Projects Representative:

WHC NFS Representative:

(NFS = New Facility Startup)

ICF KEH Representative:
Date:

Date:

Date:

Date: 


\section{WRAP ACCEPTANCE TEST PROCEDURE EXCEPTION LOG}

$\operatorname{ATP}(Y / N) Y$

ATP\#: HVAC Control ATP

Test: Table 2B

Step:

Equipment Tag \#: $\mathrm{AH}-11-401 / \mathrm{OC} \&$ UC

Spec. Section:

Test Operator: $M$ att Harper

Test Witness/Author: Keith Ealden

Responsible Contractor: $\mathrm{PCL}$

Responsible Subcontractor: Building Control Services

Responsible Individual: Matt Harper

EXCEPTION DESCRIPTION: (Expected Result versus Actual Result)

"Manual over-ride to un-occupied cycle" command issued at the PCS RTAP screen. Command was

received by the HVAC DCS system but no change in equipment status was noted.

Similar results were obtained when the "Manual over-ride to occupied cycle" command was issued at the

PCS RTAP screen.

EXCEPTION RESOLUTION:

\begin{tabular}{|l|}
\hline \\
\hline \\
\hline
\end{tabular}

Exception Closed By:

Date:

Date:

Date:

Date:
Exception: 4

Revision: 0

Execution:

Date: 26 September 1996

Time: 1340hrs

\section{APPROVAL OF RESOLUTION}

WHC NFS Representative:

(NFS = New Facility Startup)

ICF KEH Representative:

Contractor Representative:

WHC Projects Representative:

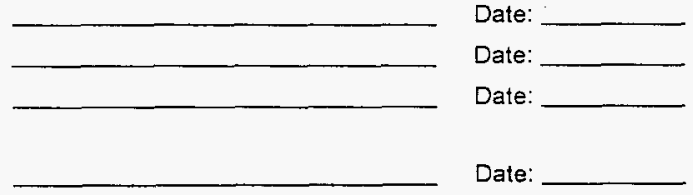




\section{WRAP ACCEPTANCE TEST PROCEDURE EXCEPTION LOG}

Exception: 5

ATP (Y/N) Y

ATP\#: HVAC Control ATP

Test: Table 9B

Step:

Equipment Tag \#: P-11-101A/B; 102AVB

Revision: 0

Execution:

Spec. Section:

Test Operator: $M$ att Harper

Test Witness/Author: Keith Ealden

Date: 26 September 1996

Time: $1535 \mathrm{hrs}$

Responsible Contractor: PCL

Responsible Subcontractor: Building Control Services

Responsible Individual: Matt Harper

EXCEPTION DESCRIPTION: (Expected Result versus Actual Result)

Stop and Start pulses for Chifled Glycol pumps P-11-101AVB and P-11-102AVB were issued at the PCS

RTAP screen. The commands were received by the HVAC DCS system but the expected changes in equipment status were not observed.

\section{EXCEPTION RESOLUTION:}

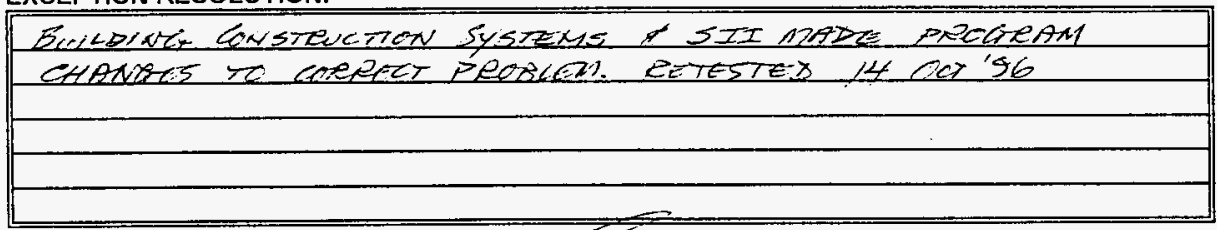

Exception Closed By:

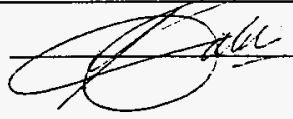

Date: $15 \mathrm{Ca}$ \&

\section{APPROVAL OF RESOLUTION}

Contractor Representative:

WHC Projects Representative:

WHC NFS Representative:

(NFS = New Facility Startup)

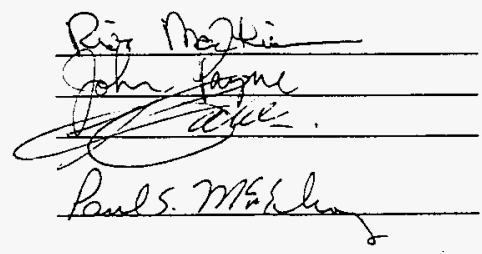

Date: $10 / 16 / 96$

Date: $10 / 16 / 96$

Date: 160426 .

ICF KEH Representative:

Date: $10 / 16 / 960$ 


\section{WRAP ACCEPTANCE TEST PROCEDURE EXCEPTION LOG}

ATP (YIN) Y ATP\#: HVAC CENTREL ATP
Test: TABLE $3 B$
Step: $3 \cdot Z: /$ Equipment Tag\#:
Spec. Section:
Test Operator: MATI HARPER
Test Witness/Author: KETTH EACDEN

Exception: 6

Revision:

Execution:

Date: 26 Sept. $\$ 6$ Time:

Responsible Contractor:

Responsible Subcontractor:

Responsible Individual:

EXCEPTION DESCRIPTION: (Expected Result versus Actual Result)

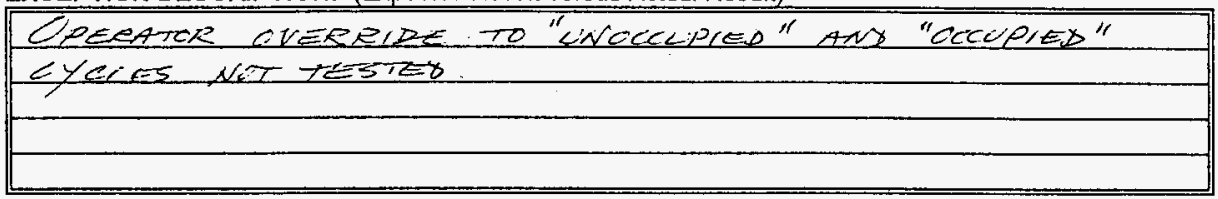

\section{EXCEPTION RESOLUTION:}

\begin{tabular}{|l|}
\hline \\
\hline \\
\hline \\
\hline
\end{tabular}

\section{Exception Closed By:}

Date:

\section{APPROVAL OF RESOLUTION}

Contractor Representative:

Date:

WHC Projects Representative:

Date:

WHC NFS Representative:

Date:

(NFS = New Facility Startup)

ICF KEH Representative:

Date: 


\section{PREREQUISITES AND EQUIPMENT REQUIRED}

1. The Andover DDC system will have to be completely installed, wired and powered up.

2. All systems that are subject to testing will have to be completely installed, wired, powered up and checked out by the unit manufacturers representative.

3. All duct systems included in systems will have to be completely instailed and sealed.

4. The following tools will be required:

- Handheld digital multi-meter.

- Laptop computer

- Screwdrivers

- Andover panel keys 
APPENDIX A - GUIDE ATP

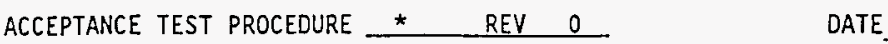

TEST TITLE

LOCATION *

PROJECT NUMBER

PROJECT TITLE *

Prepared By

For

Contract

PROCEDURE APPROVAL

originator

Checker

Project Manager
Date

Date

\section{(Company Name)}


ATP

Rev. 0

Page 1

EXECUTION AND TEST APPROVAL

EXECUTED BY

Test Director/Organization

Date Test Operator/Organization

Date

Recorder/Organization

Date

WITNESSES*

Witness/Organization

Date

Witness/Organization

Date

Witness/Organization

Date

Witness/Organization

Date

\section{A-E Approval}

Kaiser Engineers Hanford Company

ithout

exceptions

With exceptions resolved

With exceptions outstanding

Design Engineer.

Date

Project Manager

Date

TEST APPROVAL AND ACCEPTANCE*

(Operating Contractor)

Without

exceptions

With exceptions resolved

With exceptions outstanding

\section{Date (Title or Department) Date}

* NOTE TO ATP ORIGINATOR: KEH will establish project specific signatory titles or organizations during approval review.

$V-W-025-C 1$

$01655-A-1$

$6 / 1993$

Rev. 0 


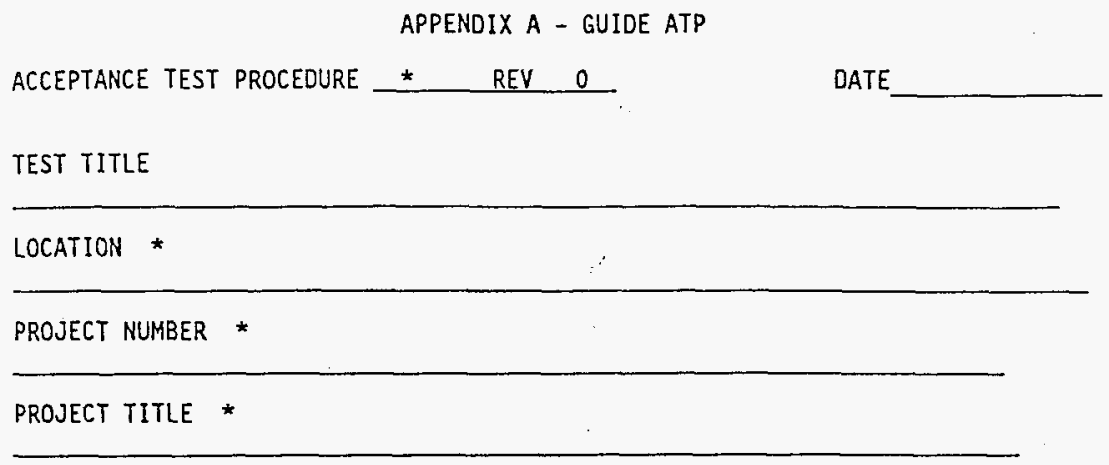

\footnotetext{
Prepared By

(Company Name)
}

For

Contract

PROCEDURE APPROYAL

Originator

Checker

Project Manager

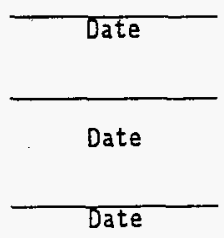

* NOTE TO ATP ORIGINATOR: Enter project specific

$V-W 026-C 1$

$01655-A-i$

$6 / 1993$

Rev. 0 


\title{
HANFORD W.R.A.P.
}

\author{
Building Control Systems
}

\section{Acceptance Test Procedure}

\author{
$\underline{\text { Submittal }}$
}

March 20, 1996 
HANFORD W.R.A.P.

\section{TABLE OF CONTENTS}

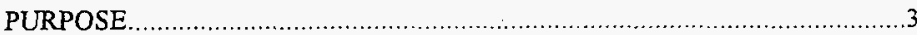

PREREQUISITES AND EQUIPMENT REQUIRED …...........................

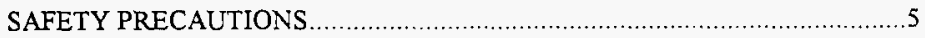

1. SHIPPING-RECEIVING AND NDE/NDA AREAS ............................

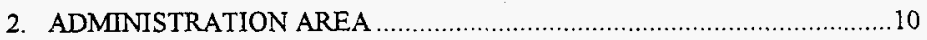

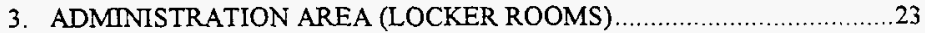

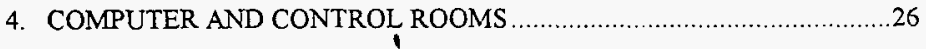

5. PROCESS AREA HVAC SYSTEMS .............................................. 31

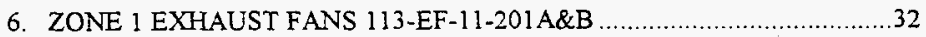

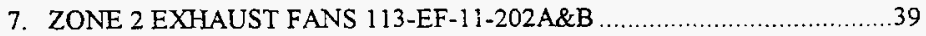

8. ZONE 1\&2 SUPPLY FANS 203-SF-11-201A\&B ..............................45

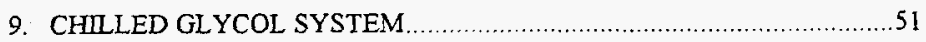

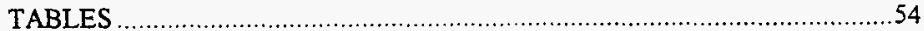


HANFORD W.R.A.P.

\section{PURPOSE}

The purpose of the test and checkout is to witness and verify that the Andover HVAC system will perform the documented sequences as specified. This test will prove that all sensors, wire, hardware, controllers, and programming are working together properly. 


\section{PREREQUISITES AND EQUIPMENT REQUIRED}

1. The Andover DDC system will have to be completely installed, wired and powered up.

2. All systems that are subject to testing will have to be completely installed, wired, powered up and checked out by the unit manufacturers representative.

3. All duct systems included in systems will have to be completely installed and sealed.

4. The following tools will be required:

- Handheld digital multi-meter.

- Laptop computer

- Screwdrivers

- Andover panel keys 
HANFORD W.R.A.P.

\section{SAFETY PRECAUTIONS}

1. All standard safety guidelines will be followed at all times.

2. If there is any possibility that equipment will be damaged during testing, the testing will be stopped immediately.

3. If the differential pressure between the PROCESS AREA and the PROCESS HVAC AREA rises above l"WC, the testing will be stopped immediately. 
HNF-SD-W026-ATR-016, Rev. 0 Page 16

HANFORD W.R.A.P.

\section{SECTION 1}

\section{SHIPPING-RECEIVING AND NDE/NDA AREAS}

\subsection{AIR HANDLING SYSTEM 203-AH-11-101:}

1.1 AH-11-101 will normally operate in accordance with the "OCCUPIED-UNOCCUPIED" schedule programmed into the Andover system.

1.2.0 Control points between HVAC DCS and the PCS for AH-11-101 will be verified on tables $1 \mathrm{~A}, 1 \mathrm{~B}$ and $1 \mathrm{C}$. These points allow the Andover control system to enunciate alarm conditions and systems variables such as supply air temperature and fan failures to the PCS. These points also allow the PCS to send commands to the Andover control system such as system start/stop signals and temperature set points. The Hardwired control points to the PCS are to enunciate air handling unit controller failures such as loss of controller power or a controller hardware malfunction.

1.2.1 AH-11-101 HVAC DCS-PCS control points completer.
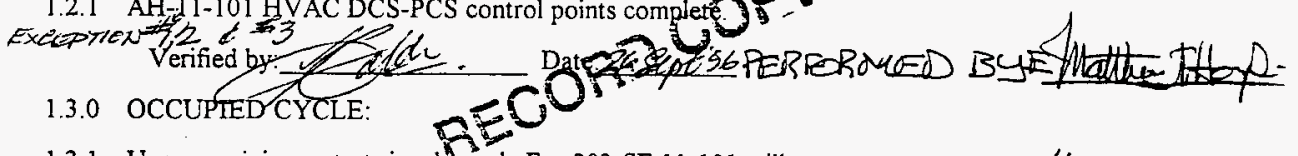

1.3.1 Upon receiving a start signal Supply Fan 203-SF-11-101 will start.

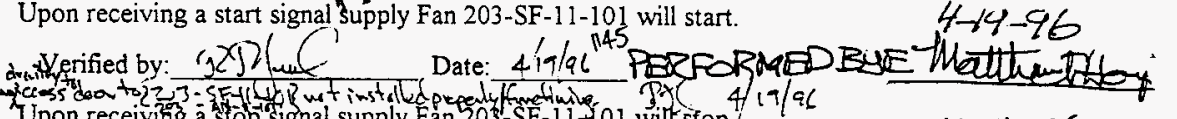

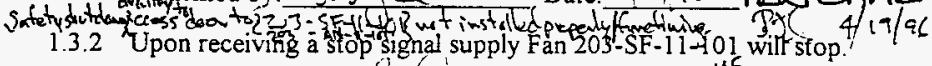

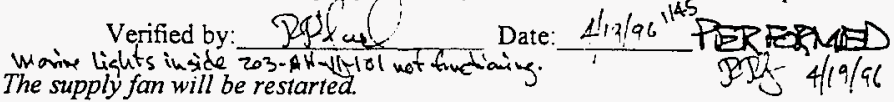
The supply fan will be restarted.

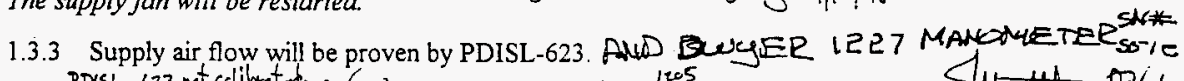

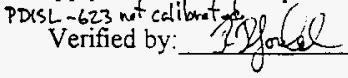

1.3.4 Supply Fan 203-SF-11-101 will be manually turned off and an alarm will be sent to the Date: $419196^{1205}$ PERTERTED Andover control system. The Return Fan 203-RF-11-101 will not operate if Supply Fan 203-SF-11-101 is not qunning.

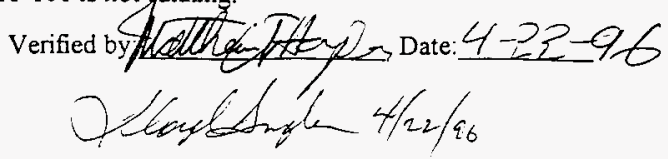


HANFORD W.R.A.P.

Supply Fan 203-SF-11-101 and the Supply Fan 203-SF-11-101 alarm points will be restored to normal operation. The test will continue with Supply Fan 203-SF-11-101 running and air flow proven by PDISL-623.

1.3.5 Return Fan 203-RF-11-101 will start.

Verified by: gins,

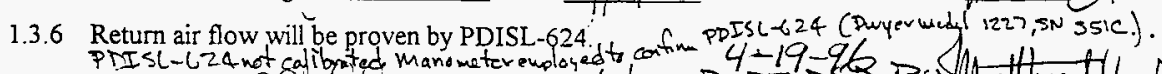

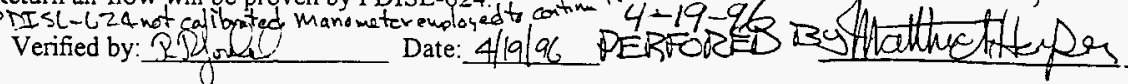

1.3.7 Return Fan 203-RF-11-101 will be manually turned off and an alarm will be sent to the Andover control system,

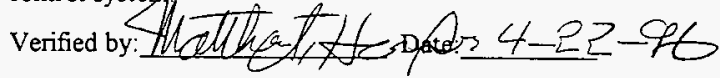

Return Fan 203-RF-11-101 and the Return Fan 203-RF-11-101 alarm points will be restored to normal operation. The test will continue with Return Fan 203-RF-11-101 running and air flow proven by PDISL-624.

1.3.8 Air solenoid valves TEV-628 and TEV-629 will energize enabling the economizer dampers.

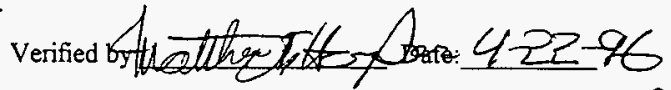

1.3.9 The outside air damper and the rectum air damper will be positioned to the minimum outside air setting by TY X-628.

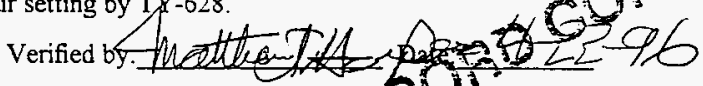

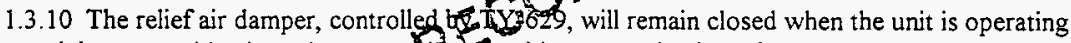
on minimum outside air setting to prove positive pressurization of the spaces served.

Verified by thatch fit s Bate: $44-22-96$

1.3.11 The NDE/NDA space temperature will be sensed by room temperature sensor TE-627 and will be maintained at a minimum of $72^{\circ} \mathrm{F}$ in winter and $78^{\circ} \mathrm{F}$ in summer.

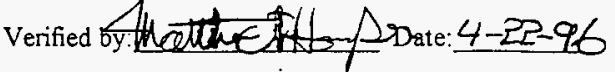

1.3.12 If the space temperature TE -627 is above setpoint and the outside air temperature is below $70^{\circ} \mathrm{F}$ then the outside air damper and relief air damper will modulate open and the return air damper will modulate closed.

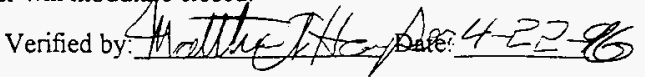

1.3.13 The temperature sensor TE-621 located in the mixed air plenum will limit the mixed air temperature from dropping below $67^{\circ} \mathrm{F}$ until the minimum outside air setting results in a lower mixed air temperature.

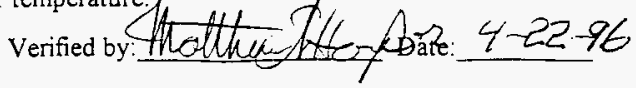

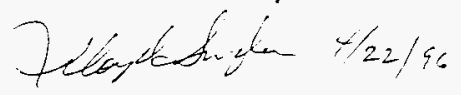

7 
1.3.14 If the space temperature TE-627 is above setpoint and the outside air temperature is above $70^{\circ} \mathrm{F}$ the outside air damper and the return air damper will return to the minimum outside air setting and the relief air damper will close. The chilled water coil valve TV- 630 controlled by TY-630 will modulate open to maintain the space temperature setpoint.

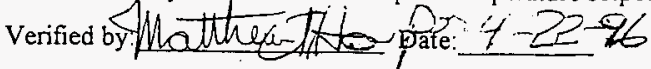

1.3.15 If the space temperature TE- 627 falls below setpoint the outside air damper and the return air damper will return to the minimum outside air setting and the relief air damper will close. The electric heating coilspvill be energized in six stages.

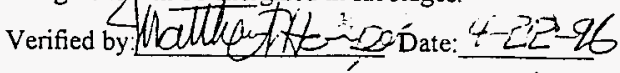

1.3.16 Temperature sensor TE-626 located in the supply air duct will limit the supply air temperature from excegding $80^{\circ} \mathrm{F}$.

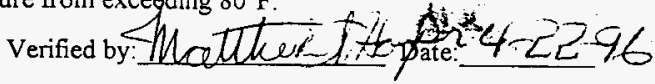

1.3.17 If differential pressure switch PDISH-621 indicates a pressure differential greater than $0.6^{\text {"WC }}$ across the pre-filter an alarm will be sent to the Andover control system.

verified by:thatthen it Date:4-E-46

1.3.18 If differential pressure switch PDISH-622 indicates a pressure differential greater than $1.0^{\prime \prime W C}$ across the final-filter an alarm will be sent to the Andover control system.

verified by thatth $11 \frac{1}{10} 4-2=-96$

\subsubsection{UNOCCUPIED CYCLE:}

1.4.1 During unoccypied cycle the system will be shut down.

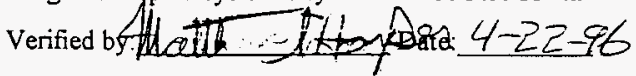

1.4.2 If the space temperature sensor TE- 627 falls to $60^{\circ} \mathrm{F}$ the system will start. The outside air damper and the relief air damper will close and the return air damper will open. The heating coils will energize.

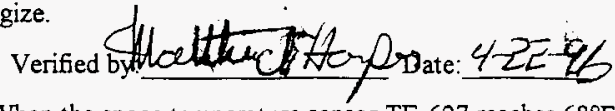

1.4.4 When the spafe temperature sensor TE- 627 reaches $68^{\circ} \mathrm{F}$ the system will shut down.

\subsubsection{FIRE ALARM SHUT DOWN:}

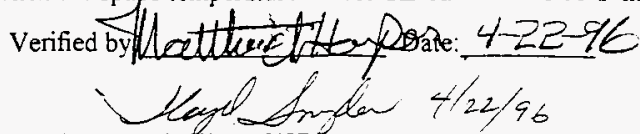

If the smoke detector (provided, Installed and wired by others) in the supply air duct is activated a signal will be sent to the central fire alarm panel (provided, Installed and wired by others) causing the supply and return air fans to shut down (interlock wiring by others). 
HANFORD W.R.A.P.

\subsubsection{ELECTRIC UNIT HEATERS:}

Electric unit heaters are provided to offset heat losses at overhead doors in the shipping and receiving and truck loading areas. A separate thermostat for each heater will cycle the fan and energize the heating element on at $68^{\circ} \mathrm{F}$.

\subsubsection{1-EH-11-10/A}

1.6.2 101-EH-11-101B

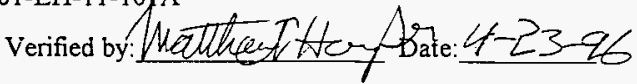

1.6 .3 100-EH-11-101C

Verified by Merithe Ritoy pate: $4-23-26$

Verified by: Héthe otterp Date: $4-23-96$

\subsubsection{0-EH-11-101D}

verified by: Watthe th thy pate:4-23-66

\subsection{EXHAUST FAN 100-EF-11-101:}

A roof mounted exhaust fan above the truck loading area to clear truck exhaust fumes will be controlled by a wall mounted hand switch. Either of the two overhead doors in this area must be open before 100-EF-11-101 can run to prevent severe disuption of space pressure.

verified by: Mathe $7 t$ thenate $4-23-26$

Gunts. Nower 4123196

1.8 AIR HANDLING SYSTEM 203-AH-11-101

COMPLETE SYSTEM CHECKOUT

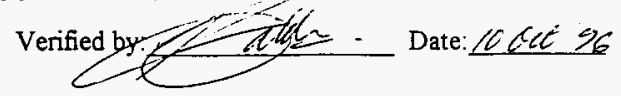




\section{SECTION 2}

\section{ADMINISTRATION AREA:}

\subsection{AIR HANDLING SYSTEM 203-AH-11-401:}

2.1 Air handler 203-AH-11-401 will normally operate in accordance with the "OCCUPIEDUNOCCUPIED" schedule programmed into the Andover system. 203-AH-11-401 is a variable air volume system with heating coils in the terminal units for each zone.

2.2.0 Control points between HVAC DCS and the PCS for AH-11-401 will be verified on tables $2 \mathrm{~A}, 2 \mathrm{~B}$ and $2 \mathrm{C}$. These points allow the Andover control system to enunciate alarm conditions and systems variables such as supply air temperature and fan failures to the PCS. These points also allow the PCS to send commands to the Andover control system such as system start/stop signals and temperature set points. The Hardwired control points to the PCS are to enunciate air handling unit controller failures such as loss of controller power or a controller hardware malfunction.

\subsubsection{AH-1 1-401,HVAC DCS-BCS control points complete.}

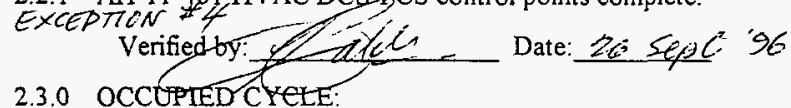

2.3.1 Upon receiving a start signal the supply fan 203-SF-11-401 will start.

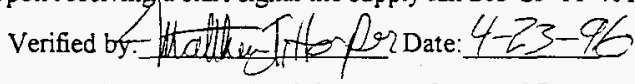

2.3.2. Upon receiving a stop signal the supply fan 203-SF-11-401 will stop.

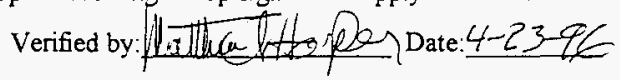

The supply fan will be restarted.

2.3.3 The supply fan inlet vanes, controlled by TY -649 , will open to the minimum CFM position of 5225 CFM as indicated by the flow monitoring station in the supply duct FE-643.

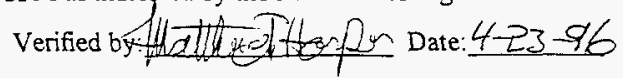

2.3.4 Supply air flow will be proven by PDISL-643.

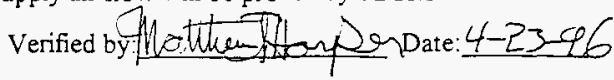


HANFORD W.R.A.P.

2.3.5 Supply Fan 203-SF-11-401 will be manually tumed off and an alarm will be sent to the Andover control system. The Retum Fan 203-RF-11-401 will not operate if Supply Fan 203-SF-11-401 is not running.

Verified by fletthe the popate $4-33-96$

Supply Fan 203-SF-11-401 and the Supply Fan 203-SF-11-401 alarm points will be restored to normal operation. The test will continue with Supply Fan 203-SF-11-401 running and air flow proven by PDISL-643.

2.3.6 The outside air damper and the return air damper will return to the minimum outside air setting and the relief air damper will remain closed.

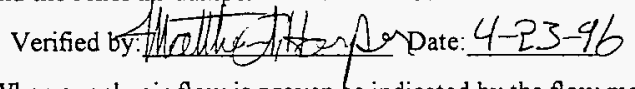

2.3.7 When supply air flow is proven as indicated by the flow monitoring station FE-643, the return fan, 203-RF-11-401, will start.

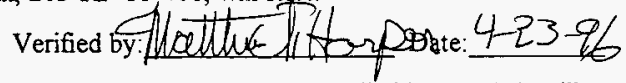

2.3.8 The retum fan inlet vanes, controlled by TY -640 , will open to the minimum CFM position of 3305 CFM as indicalted by the flow monitoring station FE-642.

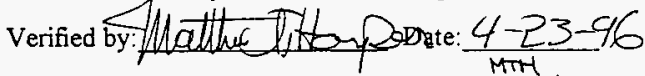

2.3.9 Retum air floy will be proven by PDISL-642: 644

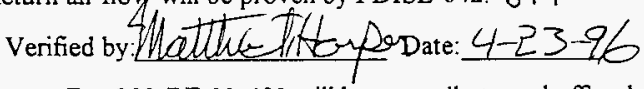

2.3.10 Return Fan 203-RF-1 1-401 will be manually tumed off and an alarm will be sent to the Andover control systemz.

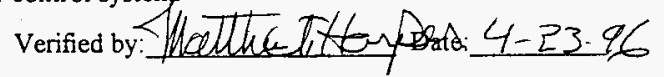

Return Fan 203-RF-11-401 and the Return Fan 203-RF-11-401 alarm points will be restored to normal operation. The test will contimue with Return Fan 203-RF-11-40I runing and air flow proven by PDISL-643

2.3.11 Supply air CFM measured by FE-643 and return air CFM measured by FE-642 will maintain a constant differential of 1920 CFM from a minimum supply air flow of 5225 CFM to a maximum supply air CFM of $11,735 \mathrm{CFM}$ to offset exhaust and provide positive space pressurization.

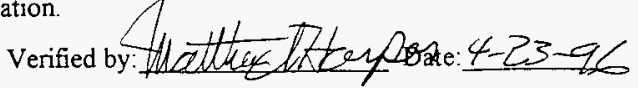

2.3.12 If the outside air temperature as indicated by $\mathrm{TE}-641$ is below $60^{\circ} \mathrm{F}$ then the temperature sensor TE- 642 located in the mixed air plenum will maintain $55^{\circ} \mathrm{F}$ by modulating the mixed air dampers.

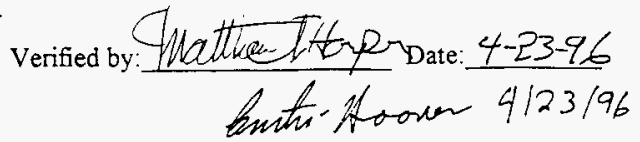


2.3.13 If the outside air temperature is above $60^{\circ} \mathrm{F}$ the outside air damper and the return air damper will return to the minimum outside air setting and the relief damper will close. The supply air temperature sensor TE- 645 wil! maintain $55^{\circ} \mathrm{F}$ supply air by modulating the cooling coil control valve TV-648 controlled by TY 648 .

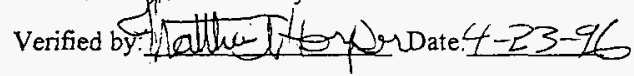

2.3.14 The supply air duct will be maintained at a constant Static pressure of 1.5"WC at the duct mounted differential pressure sensor PDT-645, the Andover system will reset the supply fan inlet vanes as the system CFM demand varies.

Verified by: hallue TitapenDate:4-24-i6

2.3.15 If differential pressure switch PDISH-641 indicates a pressure differential greater than 0.6 "WC across the pre-filter an alarm will be sent to the Andover control system.

Verified by: Hallhw Thener Date:4-24-26

2.3.16 If differential pressure switch PDISH-642 indicates a pressure differential greater than 1.0 "WC across the final-filter an alarm will be sent to the Andover control system.

Verified by Allottue Iitterper Date: $4-24-96$

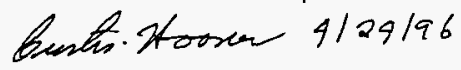




\section{HANFORD W.R.A.P.}

\subsubsection{VAV BOXES:}

2.4.1 Individual zone temperatures will be monitored by zone sensors, and maintained at $78^{\circ} \mathrm{F}$ in summer and $72^{\circ} \mathrm{F}$ in winter.

\subsubsection{151-VA-11-401: Sample Management and Corridor}

2.4.1.1 If the room temperature rises above setpoint the volume of air supplied will increase.

$$
\text { verified by-Math how If }
$$

2.4.1.2 If the room temperature drops below setpoint the volume of air supplied will decrease.

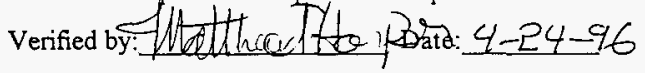

2.4.1.3 If the room temperature continues to drop after the VAV supply air has reached minimum CFM, electric heating foil will energize in 1 stage.

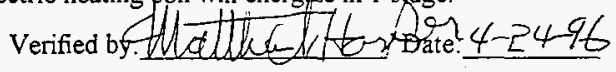

\subsubsection{151-VA-11-401 Complete}

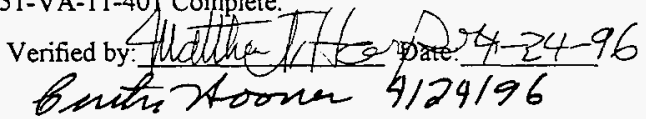

\subsubsection{139-VA-11-402: Equipment Maintenance}

2.4.2.1 If the room temperature rises above setpoint the volume of air supplied will increase.

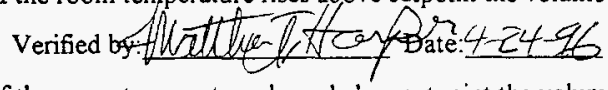

2.4.2.2 If the room temperature drops below setpoint the volume of air supplied will decrease.

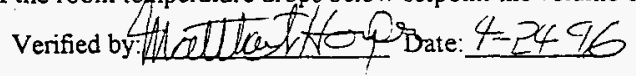

2.4.2.3 If the room temperature continues to drop after the VAV supply air has reached minimum CFM, electric heating goil will energize in 2 stages.

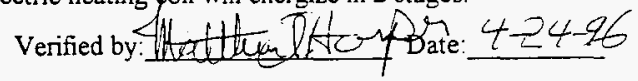

\subsubsection{139-VA-11-4Q2 Complete

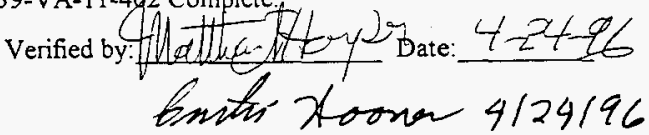




\section{HANFORD W.R.A.P.}

\subsubsection{119-VA-11-403: Telecom Room}

2.4.3.1 If the room temperature rises above setpoint the volume of air supplied will increase.

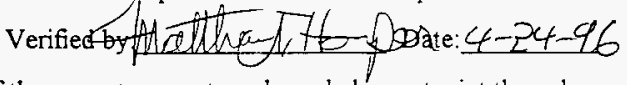

2.4.3.2 If the room temperature drops below setpoint the volume of air supplied will decrease.

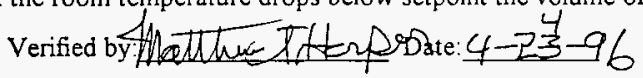

2.4.3.3 If the room temperature continues to drop after the VAV supply air has reached minimum

CFM, electric heating coil will energize in 1 stage.

verified by:thalltere the- ponate: $4-23-96$

2.4.3.4 119-VA-11-403 Complete.

24

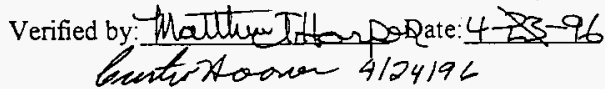

2.4.4.0 118-VA-11-404: Corridor

2.4.4.1 If the room temperature rises above setpoint the volume of air supplied will increase.

Verified by: Shattue triterpsate:4-24-96

2.4.4.2 If the room temperature drops below setpoint the volume of air supplied will decrease.

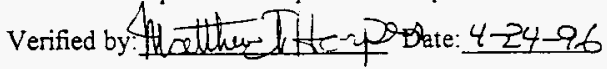

2.4.4.3 If the room temperature continues to drop after the VAV supply air has reached minimum CFM, electric heating coil will energize in 2 stages.

verified by: Matturettorperiate: $4-24-96$

2.4.4.4 118-VA-11-404 Complete.

Verified by: Ihatther THarposate: $4-24-96$

Euntustooum $4129 / 96$ 
HANFORD W.R.A.P.

2.4.5.0 118-VA-11-405: Mechanical Equipment

2.4.5. I If the room temperature rises above setpoint the volume of air supplied will increase.

Verified by thather TitfeyporDate: $4-24-96$

2.4.5.2 If the room temperature drops below setpoint the volume of air supplied will decrease.

Verified by. Mautwa Titorper Date: $4-24-96$

2.4.5.3 If the room temperature continues to drop after the VAV supply air has reached minimum CFM, electric heating coil will energize in 1 stage.

Verified by: Hatturtiterpen Date: $4-24-96$

2.4.5.4 118-VA-11-405 Complete.

verified by: Wallue Tits per Date: $\frac{4-24-96}{4 / 24 / 96}$

2.4.6.0 115-VA-11-406: UPS Room

2.4.6.1 If the room temperature rises above setpoint the volume of air supplied will increase.

Verified by. Wathere ThenperDate: $4-24-96$

2.4.6.2 If the room temperature drops below setpoint the volume of air supplied will decrease.

Verified by: Mottlue therpuate: $4-24-26$

2.4.6.3 If the room temperature continues to drop after the VAV supply air has reached minimum CFM, electric heating coil will energize in 2 stages.

Verified by: Worthereterperpate: $4-24-96$

2.4.6.4 115-VA-11-406 Complete.

Verified by: Ihe the tit arperDate: 4-24-96

bute-70owen 4/24196 
HANFORD W.R.A.P.

\subsubsection{116-VA-1 1-407: Electrical Room}

2.4.7.1 If the room temperature rises above setpoint the volume of air supplied will increase.

verified by Allatthatifoyer Date:4-24-96

2.4.7.2 If the room temperature drops below setpoint the volume of air supplied will decrease.

Verified by flutolthe Therperpate: $4-24-96$

2.4.7.3 If the room temperature continues to drop after the VAV supply air has reached minimum CFM, electric heating coil will energize in 2 stages.

Verified by: Malltwe Juteper Date: $4-24-96$

2.4.7.4 116-VA-11-407 Complete.

Verified by: Matther IitterperDate: 4-24-96

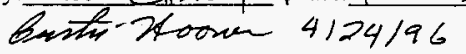

2.4.8.0 152-VA-1 1-408: Material Preparations Area

2.4.8.1 If the room temperature rises above setpoint the volume of air supplied will increase.

verified by: Shather Tterper Date: 4-24-96

2.4.8.2 If the room temperature drops below setpoint the volume of air supplied will decrease.

verified by:fllathe Tito operDate: 4-24-96

2.4.8.3 If the room temperature continues to drop after the VAV supply air has reached minimum CFM, electric heating coil will energize in 1 stage.

verified by Wolther THo-porDate: $4-24-96$

2.4.8.4 152-VA-11-408 Complete.

Verified by: Watthere THorper Date: $4-24-96$

buth. Poover 4124196 
HANFORD W.R.A.P.

2.4.9.0 102-VA-11-409: Shipping and Receiving Office

2.4.9.1 If the room temperature rises above setpoint the volume of air supplied will increase.

verified by Aluattumterpir Date: $4-24-96$

2.4.9.2 If the room temperature drops below setpoint the volume of air supplied will decrease.

Verified by: Matthenterper Date: 4-24-96

2.4.9.3 If the room temperature continues to drop after the VAV supply air has reached minimum CFM, electric heating coil will energize in 1 stage.

Verified by: the thther Interper Date: $4-24-96$

2.4.9.4 102-VA-11-409 Complete.

Verified by: Malute Thterperate: $\frac{4-24-96}{4124196}$

2.4.10.0 130-VA-11-410: Corridor

2.4.10.1 If the room temperature rises above setpoint the volume of air supplied will increase.

Verified by fuather Titterperpate: $4-24-96$

2.4.10.2 If the room temperature drops below setpoint the volume of air supplied will decrease.

Verified by: Hothte-Itterpen Date: $4-24-96$

2.4.10.3 If the room temperature continues to drop after the VAV supply air has reached minimum CFM, electric heating coil will energize in 3 stages.

Verified by: Hattue tetorporate: $4 \geq 4-96$

2.4.10.4 130-VA-11-410 Complete.

Verified by: Mauther tifterporate: 4-24-i6

Gutir-1toover 4124196 
HANFORD W.R.A.P.

2.4.11.0 129-VA-11-411: Lunch Room

2.4.11.1 If the room temperature rises above setpoint the volume of air supplied will increase.

Verified by: Hatther Tonpes Date: $4-24-96$

2.4.11.2 If the room temperature drops below setpoint the volume of air supplied will decrease.

Verified by: Malturen Thterper Date: $4-24-96$

2.4.11.3 If the room temperature continues to drop after the VAV supply air has reached minimum CFM, electric heating coil will energize in 3 stages.

Verified by: thatutere Thtorper Date: $4-24-96$

2.4.11.4 129-VA-11-411 Complete.

Verified by: Alathue Iitemper Date: $\frac{4-24-96}{4129196}$

2.4.12.0 128-VA-11-412: Conference Room

2.4.12.1 If the room temperature rises above setpoint the volume of air supplied will increase.

Verified by: Mallhe Tatorper Date: 4-24-96

2.4.12.2 If the room temperature drops below setpoint the volume of air supplied will decrease.

Verified by: Awalther THayper Date: $424-86$

2.4.12.3 If the room temperature continues to drop after the VAV supply air has reached minimum CFM, electric heating coil will energize in 3 stages.

\section{Verified by: IMathereTterper Date: $4-24-76$}

2.4.12.4 128-VA-11-412 Compiete.

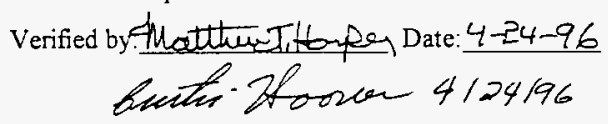


HANFORD W.R.A.P.

\subsubsection{126-VA-11-413: Operations Manager RCD, MGT and Storage}

2.4.13.1 If the room temperature rises above setpoint the volume of air supplied will increase.

Verified by thatherenterpes Date:4-24-96

2.4.13.2 If the room temperature drops below setpoint the volume of air supplied will decrease.

Verified by: Whathure Aleyper Date:4-24-96

2.4.13.3 If the room temperature continues to drop after the VAV supply air has reached minimum CFM, electric heating coil will energize in 3 stages.

Verified by. Altalture Thtorper Date: 4-24-96

2.4.13.4 126-VA-11-413 Complete.

Verified by: Whathe $T_{1}$ terper Date:4-24-96

2.4.14.0 120-VA-11-414: RPT

2.4.14.1 If the room temperature rises above setpoint the volume of air supplied will increase.

Verified by Huantur Tttorper Date: $4-24-96$

2.4.14.2 If the room temperature drops below setpoint the volume of air supplied will decrease.

Verified by AMathetitenper Date: $4-24-96$

2.4.14.3 If the room temperature continues to drop after the VAV supply air has reached minimum CFM, electric heating coil will energize in 1 stage.

Verified by:Matcher. TiterperDate: 4-24-96

2.4.14.4 120-VA-11-414 Complete.

Verified by. Allattur-titeper Date:4-24-96

Eunter tower 4124196 
HANFORD W.R.A.P.

2.4.15.0 125-VA-11-415: Sec and Rec/Waiting Area

2.4.15.1 If the room temperature rises above setpoint the volume of air supplied will increase.

Verified by: thathum Intorper Date:4-24-96

2.4.15.2 If the room temperature drops below setpoint the volume of air supplied will decrease.

Verified by: Hattheriterper Date: $4-24-96$

2.4.15.3 If the room temperature continues to drop after the VAV supply air has reached minimum CFM, electric heating coil will energize in 3 stages.

Verified by: Malthe Trtouper Date: $4-24-96$

2.4.15.4 125-VA-11-415 Complete.

verified by: Waltweritterper Date: $\frac{4-24-96}{124196}$

2.4.16.0 203-VA-11-416: HVAC Equipment Room

2.4.16.1 If the room temperature rises above setpoint the volume of air supplied will increase.

Verified by. Alatulue Tuterper Date: $4-24-26$

2.4.16.2 If the room temperature drops below setpoint the volume of air supplied will decrease.

Verified by Whather Thterpen Date: 4-24-96

2.4.16.3 If the room temperature continues to drop after the VAV supply air has reached minimum CFM, electric heating coil will energize in 1 stage.

Verified by utaterteren Date: $4-24-96$

2.4.16.4 203-VA-11-416 Complete.

Verified by: Ahatther Ttterper Date:4-24-96

buitu Xown 4/24196 
HANFORD W.R.A.P.

\subsubsection{UNOCCUPIED CYCLE:}

2.5.1 During the unoccupied cycle the system will shut down

verified by fhathentitterpen Date:4-24-96

2.5.2 If the temperature sensor in the Operations Manager's office (TE-646K) falls to $60^{\circ} \mathrm{F}$, the supply fan 203-SF-11 401 will start, then the return fan 203-RF-11-401 will start.

Verified by:thalluyedthenen Date:4-24-96

2.5.3 The outside air damper and relief air damper will remain closed and the return air damper will remain open.

verified by: Maltue interporde:4-24-96

2.5.4 The exhaust fans will remain off.

Verified by: Shatture Dtarpote: 4 F24-26

2.5.5 The return air CFM will equal the supply air CFM.

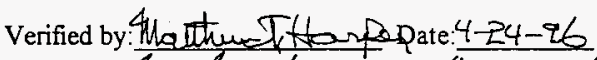

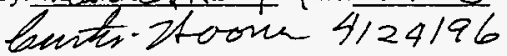

\subsubsection{EXHAUST FANS:}

2.6.1 Toilet exhaust fan, 203-EF-11-401 will be interlocked to run when 203-RF-11-401 is operating during the occupied cycle.

Verified by: thathertorer Date: 4-24-96

2.6.2 Material prep room exhaust fan, 152-EF-1 1-402 will operate from a manual wall switch oniy if 203-RF-11-401 is running.

Verified by: Date:

\subsection{FIRE ALARM SHUT DOWN:}

If the smoke detector (provided, Installed and wired by others) in the supply air duct is activated a signal will be sent to the central fire alarm panel (provided, Installed and wired by others) causing the supply, return and exhaust air fans to shut down (interlock wiring by others). 
HANFORD W.R.A.P.

\subsubsection{ELECTRIC UNIT HEATERS:}

Each electric unit heater will be cycled from a wall mounted thermostat.

2.8 .1 152-EH-11-401

Verified by. Halluerithapes Date: $4-24-96$

2.8.2 203-EH-11-402A

Verified by: Matther

2.8 .3 203-AH-11-402B

Verified by: Wadtreentarfer Date: $4-24-96$

2.8 .4 203-AH-11-402C

Verified by: Watthar The perDate:424-96

bunte. Howner $4 / 24196$

2.9 AIR HANDLING SYSTEM 203-AH-11-401

COMPLETE SYSTEM CHECKOUT

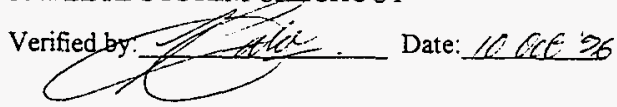




\section{$\underline{\text { SECTION } 3}$}

\section{ADMINISTRATION AREA (LOCKER ROOMS)}

\subsection{AIR HANDLING SYSTEM 203-AH-11-301 / EXHAUST FAN 203-RF-1 1-301:}

3.1 This system will normally operate in accordance with the "OCCUPIED-UNOCCUPIED" schedule programmed into the Andover Control System. The system used 100\% outside air to ventilate the locker room area.

3.2.0 Control points between HVAC DCS and the PCS for AH-11-301 will be verified on tables $3 \mathrm{~A}, 3 \mathrm{~B}$ and $3 \mathrm{C}$. These points allow the Andover control system to enunciate alarm conditions and systems variables such as supply air temperature and fan failures to the PCS. These points also allow the PCS to send commands to the Andover control system such as system start/stop signals and temperature set points. The Hardwired control points to the PCS are to enunciate air handling unit controller failures such as loss of controller power or a controller hardware malfunction.

\subsubsection{AH-11-401 HVAC DCS-PCS control points complete. Exceprter *6 3.3 .0 Verified by dathedte por Date: $\frac{4-23-96}{50}$ sept}

3.3.1 Upon receiving a start signal, FEV-661 will enable the outside air damper and the exhaust air damper to open fully.

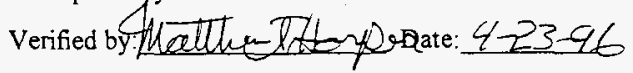

3.3.2 The supply fan 203-SF-11-301 will start and airfow will be proven by PDISL-663.

verified by: Ihattlestey ate: $4-23-26$

3.3.3 Upon receiving a stop signal, FEV-661 will disable and close fully the outside air damper and the exhaust air damper.

verified by Hatthe It topepate $423-96$

3.3.4 The supply fan 203-SF-11-301 will stop.

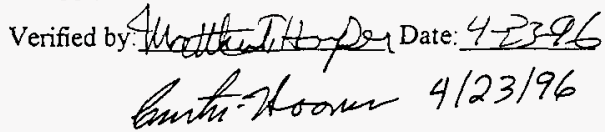


HANFORD W.R.A.P.

The supply fan will be restarted.

3.3.5 Supply Fan 203-SF-11-301 will be manually turned off and an alarm will be sent to the Andover control system. The Exhaust Fan 203-EF-11-301 will not operate if Supply Fan 203-SF-11-301 is not running.

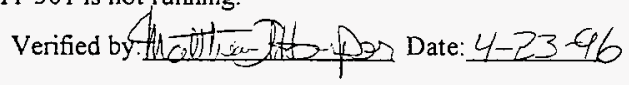

Supply Fan 203-SF-11-301 and the Supply Fan 203-SF-11-301 alarm points will be restored to normal operation. The test will continue with Supply Fan 203-SF-11-301 running and air flow proven by PDISL-663.

3.3.6 The exhaust fan 203-EF-11-301 will start.

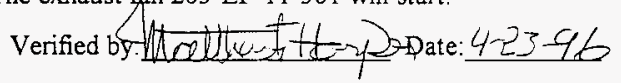

3.3.7 The locker room temperature sensor TE- 668 will maintain a minimum of $72^{\circ} \mathrm{F}$ in winter and $78^{\circ} \mathrm{F}$ in summer.

Verified by fusti wenther per Date: $4-23-96$

3.3.8 If the room temperature sensor TE-668 is above setpoint the chilled glycol coil control valve TV-666, controlled by TY-666, will modulate open to maintain the room setpoint.

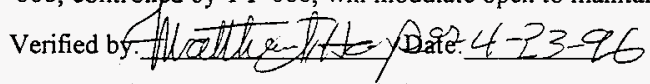

3.3.9 The supply air sensor TE-665 will limit the supply air temperature from dropping below $60^{\circ} \mathrm{F}$.

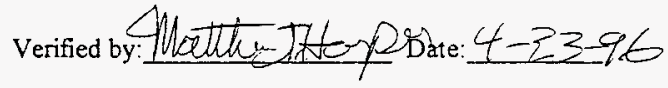

3.3.10 If the room temperature sensor TE-668 is below setpoint and the cooling control valve TV-666 is fully closed, the electric heating coil will be energized in eight stages.

Verified by: Date:

3.3.11 The supply air sensor TE- 665 will limit the supply air temperature from rising above $80^{\circ} \mathrm{F}$.

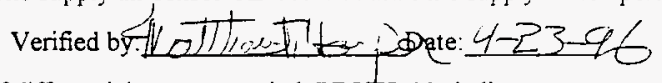

3.3.12 If differential pressure switch PDISH-661 indicates a pressure differential greater than 0.6 "WC across the pre-filter an alarm will be sent to the Andover control system.

verified by: thatthy titerebrate: $4-2396$

3.3.13 If differential pressure switch PDISH-662 indicates a pressure differential greater than 1.0"WC across the final-filter an alarm will be sent to the Andover control system.

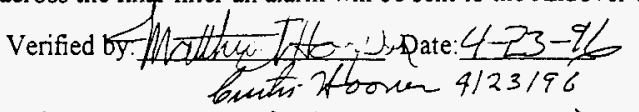

* aUX DUCT heAtER (stages 7 b8) will not funotion. 
HANFORD W.R.A.P.

\subsubsection{UNOCCUPIED CYCLE:}

3.4.1 During the ungccupied cycle the system will be shut down.

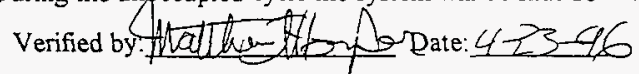

3.4.2 If the room temperature sensor TE-668 falls to $60^{\circ} \mathrm{F}$ the fans will start and the heating coil will be energized.

Verified by. Halluests, Dote: $4-23-96$

3.4.3 When the spage temperature reaches $68^{\circ} \mathrm{F}$ the system will shut down.

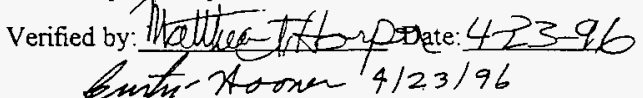

\subsection{FIRE ALARM SHUT DOWN:}

If the smoke detector (provided, Installed and wired by others) in the supply air duct is activated a signal will be sent to the central fire alarm panel (provided, Installed and wired by others) causing the supply and exhaust air fans to shut down (interlock wiring by others).

3.6 AIR HANDLNG SYSTEM 203-AH-11-301

COMPLETE SYSTEM CHECKOUT

Verified by:

Date: 


\section{SECTION 4}

\section{COMPUTER AND CONTROL ROOMS}

\subsection{AIR HANDLING SYSTEM 203-AH-11-501A AND B:}

4.1.0 Control points between HVAC DCS and the PCS for AH-11-501A \& B will be verified on tables $4 \mathrm{~A}, 4 \mathrm{~B}$ and $4 \mathrm{C}$. These points allow the Andover control system to enunciate alarm conditions and systems variables such as supply air temperature and fan failures to the PCS. These points also allow the PCS to send commands to the Andover control system such as system start/stop signals and temperature set points. The Hardwired control points to the PCS are to enunciate air handling unit controller failures such as loss of controller power or a controller hardware malfunction.

4.1.1 AH-11-501A \& B HVAC DCS-PCS control points complete.

4.2 Redurndant thandlers arranged for active/standby operation serve the computer and control rooms. The active unit will operate 24 hours per day. The Andover system will alternate the active/standby status of the units every seven days.

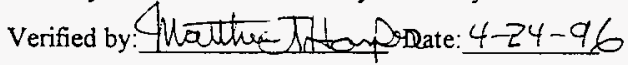

4.3 AIR HANDLING SYSTEM 203-AH-11-501A: As the active unit, 203-AH-11-501B as the standby unit.

4.3.1 Upon receiving a start signal TEV-638A will enable and open fully the isolation dampers 203-DP-11-501A and 203-DP-11-502A.

verified by the there Attcy 0 bate: 4-24-96

4.3.2 Supply fan 203-SF-11-501A will be proven by PDISL-633A

Verified bf Hoettur Ittoy Date: $424-26$

4.3.3 Upon receiving a stop signal TEV-638A will disable and close fully the isolation dampers 203-DP-11-501A and 203-DP-11-502A.

Verified by Meetufent thopen Date:4-24-26 
4.3.4 Supply fan 203-SF-11-501A will stop.

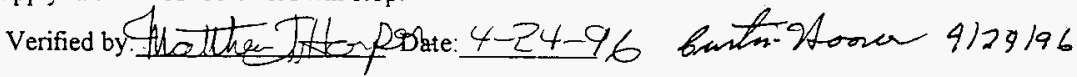

The supply fan will be restarted.

4.3.5 Supply Fan 203-SF-11-501 A will be manually turned off and an alarm will be sent to the Andover control system.

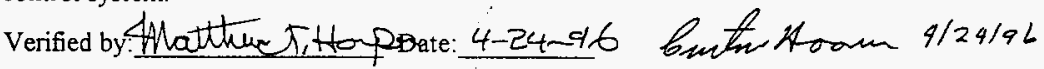

Supply Fan 203-SF-11-501A and the Supply Fan 203-SF-11-501A alarm points will be restored to normal operation. The test will continue with Supply Fan 203-SF-11-501A running and air flow proven by PDISL-663A.

4.3.6 The outside air damper and the return air damper will travel to the minimum outside air setting and the relief damper will remain closed.

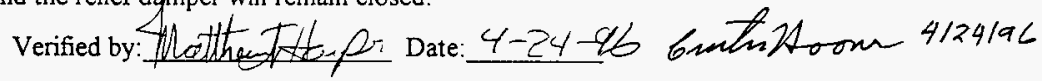

4.3.7 The room temperature sensor TE-632A will maintain $72^{\circ} \mathrm{F}$.

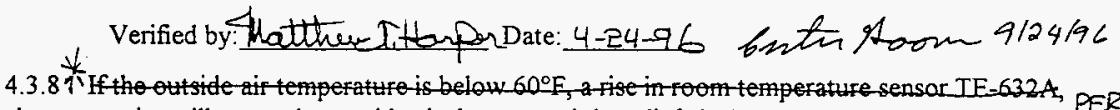
abo setpoint willease thoutside air damper the relief air damper-to and

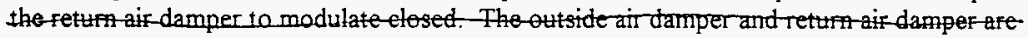
modutat by $\mathrm{TY}-63 \mathrm{~A}$ and the relief air damper by $\mathrm{TY}-632 \mathrm{~A}$

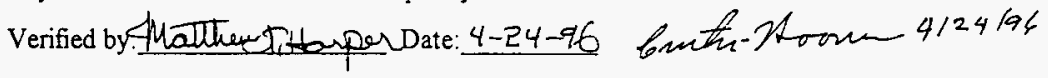

4.3.9 If the outside air temperature is above $60^{\circ} \mathrm{F}$ the outside air and return air dampers will return to a minimum outside air setting and the relief air damper will close, a rise in room temperature sensor TE-632A above setpoint will cause the chilled glycol cooling coil valve TV-638A, controlled by TY-638A, to modulate open to maintain room temperature setpoint.

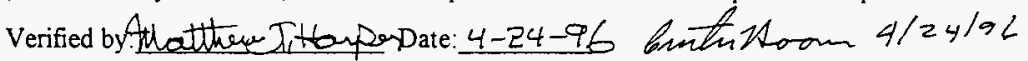

4.3.10 The supply air sensor TE-637A will limit the supply air from dropping below $55^{\circ} \mathrm{F}$.

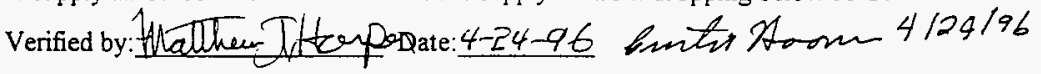

4.3.11 If room temperature sensor TE-632A drops below room temperature setpoint, the outside air and return air dampers will return to a minimum outside air setting and the relief air damper will close. The electric heating coil will energize in three stages.

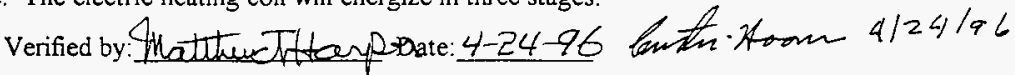

4.3.12 The supply air sensor TE-637A will limit the supply air from rising above $80^{\circ} \mathrm{F}$.

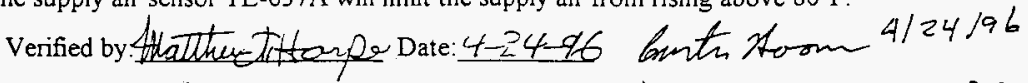

XIFTHE OUTSICE FISR TEMPERATERE IS IELOW 6OF A RISE. IN RONM TEMPSRATUPE

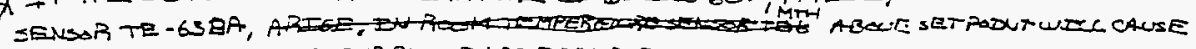

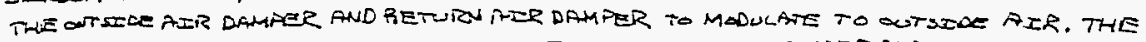

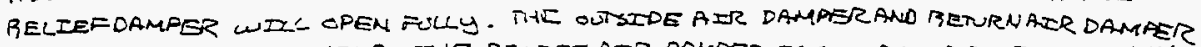

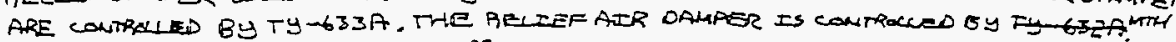


HANFORD W.R.A.P.

4.3.13 Room humidity sensor ME-632A will maintain a minimum of $30 \% \mathrm{RH}$ by sequencing a two stage humidifier located in the supply air duct with a 4-20ma control signal.

Verified by: Date:

4.3.14 If differential pressure switch PDISH-631 A indicates a pressure differential greater than 0.6 "WC across the pre-filter an alarm will be sent to the Andover control system.

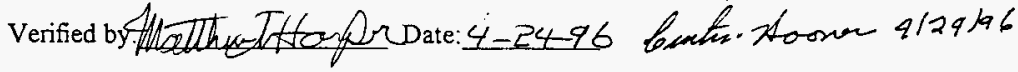

4.3.15 If differential pressure switch PDISH-632A indicates a pressure differential greater than 1.0 "WC across the final-filter an alarm will be sent to the Andover control system.

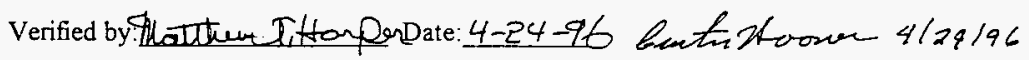

4.3.16 Upon a loss of airflow in 203-AH-11-501A or failure to maintain the room temperature setpoint the Andover system will shut down 203-AH-11-501 A, set 203-AH-11-501B as the active unit and provide an alarm signal to the PCS.

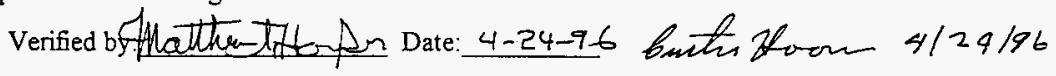

\subsubsection{FIRE ALARM SHUT DOWN:}

If the smoke detector (provided, Installed and wired by others) in the supply air duct is activated a signal will be sent to the central fire alarm panel (provided, Installed and wired by others) causing the supply fan to shut down (interlock wiring by others).

\subsubsection{AIR HANDLING SYSTEM 203-AH-11-501A \\ COMPLETE SYSTEM CHECKOUT}

Verified by:

Date: 
HANFORD W.R.A.P.

4.4.0 AIR HANDLING SYSTEM 203-AH-11-501B: As active unit, 203-AH-11-501A as standby unit.

4.4.1 Upon receiving a start signal TEV-638B will enable and open fully the isolation dampers 203-DP-11-501B and 203-DP-11-502B.

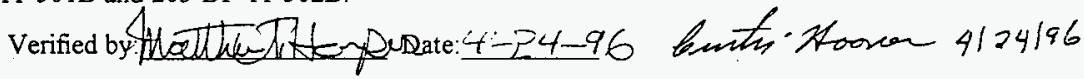

4.4.2 Supply fan 203-SF-11-501B will start and will be proven by PDISL-633B

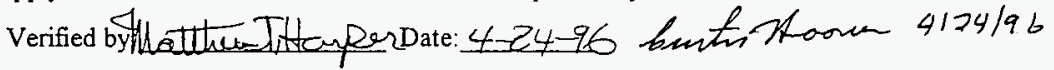

4.4.3 Upon receiving a stop signal TEV-638B will disable and close fully the isolation dampers 203-DP-11-501B and 203-DP-11-502B.

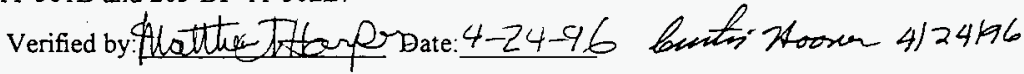

4.4.4 Supply fan 203-SF-1 1-501B will stop.

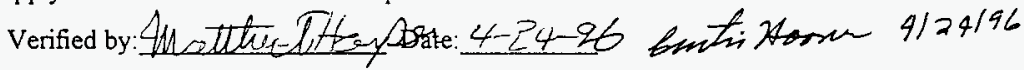

The supply fan will be restarted.

4.4.5 Supply Fan 203-SF-11-501B will be manually turned off and an alarm will be sent to the Andover control system.

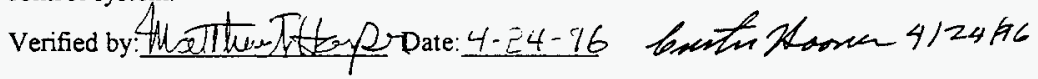
Supply Fan 203-SF-11-501B and the Supply Fan 203-SF-11-501B alarm points will be restored to normal operation. The test will continue with Supply Fan 203-SF-11-501B running and air flow proven by PDISL-663A.

4.4.6 The outside air damper and the retum air damper will travel to the minimum outside air setting and the relief damper will remain closed.

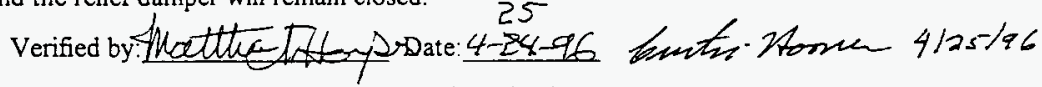

4.4.7 The room temperature sensor TE-632B will maintain $72^{\circ} \mathrm{F}$.

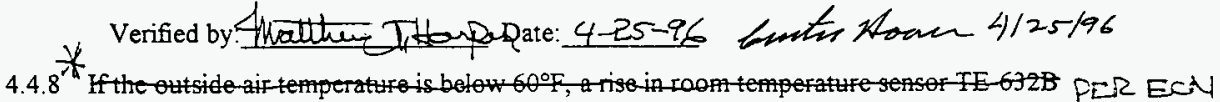
aboverpoint withatso outsid damper and the relief air damper to modulate opent the tumair damper to modulate tosed. Theoutside-air damper and are

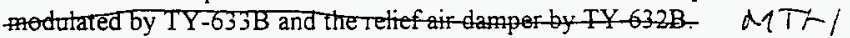

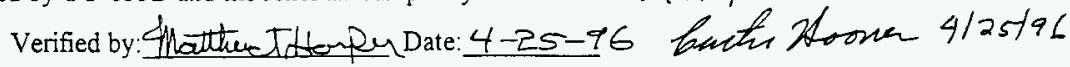

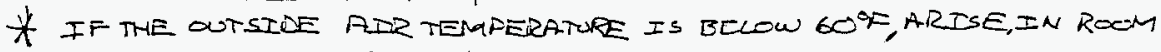

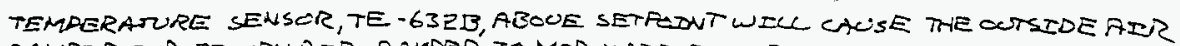

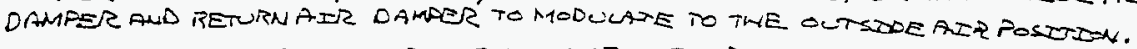
THE BELIEF DFMPER WIL OPEN FULYY THE OUTSCDE ADR DAMPER ANW RETUN ADV DAMPER ARE CONTRQLED BY TY-633A.THE RELIEPAER DAMPER IS CONTROLLD BY PYy TEN $632 B$ 


\section{HANFORD W.R.A.P.}

4.4.9 If the outside air temperature is above $60^{\circ} \mathrm{F}$ the outside air and return air dampers will return to a minimum outside air setting and the relief air damper will close, a rise in room temperature sensor TE-632B above setpoint will cause the chilled glycol cooling coil valve TV-638B, controlled by TY-638B, to modulate open to maintain room temperature setpoint.

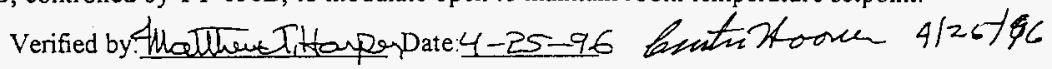

4.4.10 The supply air sensor TE-637B will limit the supply air from dropping below $55^{\circ} \mathrm{F}$.

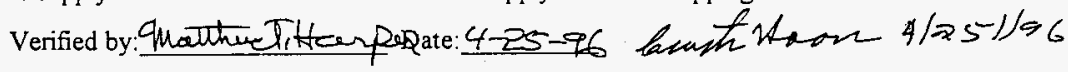

4.4.11 If room temperature sensor TE-632B drops below room temperature setpoint, the outside air and return air dampers will return to a minimum outside air setting and the relief air damper will close. The electric heating coil will energize in three stages.

Verified by: Mattluetrtenpepate:4-25-76 buth thowe 4/25/96

4.4.12 The supply air sensor TE-637B will limit the supply air from rising above $80^{\circ} \mathrm{F}$.

verified by: WatturetterperDate:4-25-96 bath thom 4/75/96

4.4.13 Room humidity sensor ME-632B will maintain a minimum of $30 \% \mathrm{RH}$ by sequencing a two stage humidifier located in the supply air duct with a $4-20 \mathrm{ma}$ control signal.

Verified by Date:

4.4.14 If differential pressure switch PDISH-631B indicates a pressure differential greater than 0.6 "WC across the pre-filter an alarm will be sent to the Andover control system.

verified by: Matther TittorporDate: 4-25-96 fersthi Hoow 4/25ta 6

4.4.15 If differential pressure switch PDISH-632B indicates a pressure differential greater than 1.0"WC across the finai-filter an alarm will be sent to the Andover control system.

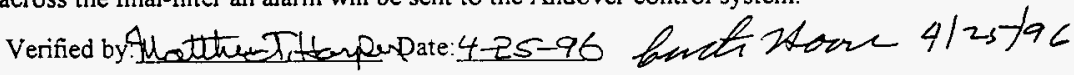

4.4.16 Upon a loss of airflow in 203-AH-11-501B or failure to maintain the room temperature setpoint the Andover system will shut down 203-AH-11-501B, set 203-AH-11-501A as the active unit and provide an alarm signal to the PCS.
verified by: fll allt Te D Date: $4-24-96$
lonter hoon i1 2519

\subsubsection{FIRE ALARM SHUT DOWN:}

If the smoke detector (provided, Installed and wired by others) in the supply air duct is activated a signal will be sent to the central fire alarm panel (provided, Installed and wired by others) causing the supply fan to shut down (interlock wiring by others).

\subsubsection{AIR HANDLING SYSTEM 203-AH-11-501B}

COMPLETE SYSTEM CHECKOUT

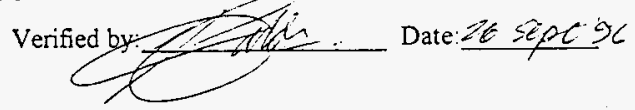




\section{SECTION 5}

\section{PROCESS AREA HVAC SYSTEMS:}

5.0 Redundant exhaust fans and air handling units arranged for active/standby operation are provided for the process area. In no case will redundant units be connected to the same HVAC controller. Changeover from the active/standby status will require operator input to the Plant Control System (PCS) or direct to the Andover Control System except in the case of a failure of the active unit which will result in an automatic switchover by the Andover Control System to the standby unit, shutdown of the failed unit and an alarm set by the Andover Control System shall be reported to the PCS. 


\section{SECTION 9}

\section{CHILLED GLYCOL SYSTEM:}

9.0 The chilled glycol system consists of two air-cooled reciprocating chillers

118-CH-11-101A and 118-CH-11-101B piped in parallel with a dedicated circulation pumps 118-P-11-102A and 118-P-11-102B, respectively per chiller. The chiller circulation pumps are piped in a secondary circuit to the primary chilled glycol distribution circuit which has redundant pumps 118-P-11-101A and 118-P-11-101B in a active/standby arrangement.

9.1.0 Control points between HVAC DCS and the PCS for CH-11-101A \& B will be verified Exeeprot on tables $9 \mathrm{~A}, 9 \mathrm{~B}$ and $9 \mathrm{C}$. These points allow the Andover control system to enunciate alarm conditions and systems variables such as supply air temperature and fan failures to the PCS. These points also allow the PCS to send commands to the Andover control system such as system start/stop signals and temperature set points. The Hardwired control points to the PCS are to enunciate air handling unit controller failures such as loss of controller power or a controller hardware malfunction.

9.1.1 The Andover Control System will automatically alternate lead/lag status of the chillers and chiller circulation pumps every seven days.

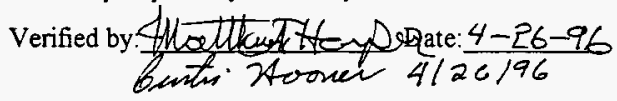

9.2.0 CHILLER 118-CH-11-101A and PUMPS 118-P-11-101A and 118-P-11-102A as the active system.

9.2.1 When the outside air temperature reaches $58^{\circ} \mathrm{F}$ the Andover Control System will start 118-P-11-101A.

verified by: Walther titorperDate:4-26-96 fustur Hoom 4/26196

9.2.2 When the flow switch FS-654 in the primary distribution circuit proves circulation, circulation pump 118-P-11-102A will start.

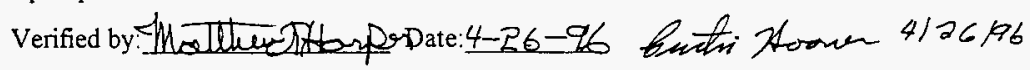

9.2.3 The Andover Control System will enable chiller 118-CH-11-101A, when the chiller's factory furnished operating and safety controls are enabled, the chiller will start.

Verified by: Mattur-TterporDate:4-26-96 fouth Hoom 4/26196

9.2.4 Chiller 118-CH-11-101 A will maintain $44^{\circ} \mathrm{F}$ leaving chilled glycol by loading/unloading cylinders and sequencing compressors on and off. This is not a Function of the Andover control System and is internal to chiller 118-CH-11-101A. 
HANFORD W.R.A.P.

9.2.5 When the cooling load rises above the capacity of a single chiller and the flow switch FS-653 in the primary-secondary bridge leg detects a flow of approximately 30 GPM recirculation in the primary distribution circuit, the Andover Control System will activate the 118-CH-11-101B system.

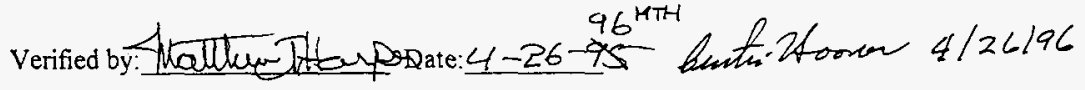

9.2.6 The chilled glycol system will operate with both chillers on-line until the load decreases to approximately $80 \%$ of the capacity of a single chiller. "This condition occurs when the venturi pressure transducer FE-652 senses approximately 180 GPM recirculation in the secondary circuit. At this time the chiller 118-CH-11-101B will shut down. $96^{\mathrm{MTH}}$

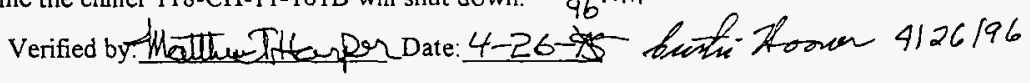

9.2.7 The chiller 118-CH-11-101A system will continue to operate until the outside air temperature drops to $55^{\circ} \mathrm{F}$.

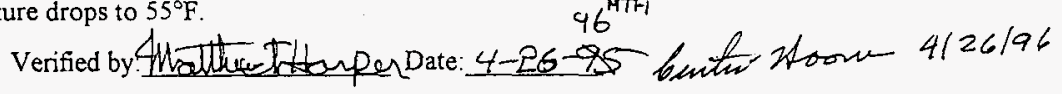

9.2.8 Chiller 118-CH-11-101A system complete.

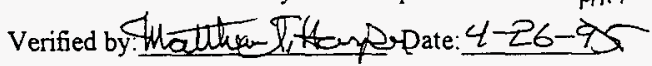

bristin Hooner 4126196 
HANFORD W.R.A.P.

9.3.0 CHILLER 118-CH-11-101B and PUMPS 118-P-11-101B and 118-P-11-102B as the active system.

9.3.1 When the outside air temperature reaches $58^{\circ} \mathrm{F}$ the Andover Control System will start 118-P-11-101B.

Verified by: Malltertterpes Date:4-26-96 bustes. 2 toosen 4126196

9.3.2 When the flow switch FS-654 in the primary distribution circuit proves circulation, circulation pump 118-P-11-102B will start.

Verified by: Malltwe JitarporDate: 4-26-96 buctiptooven 4/26196

9.3.3 The Andover Control System will enable chiller 118-CH-11-101B, when the chiller's factory furnished operating and safety controls are enabled, the chiller will start.

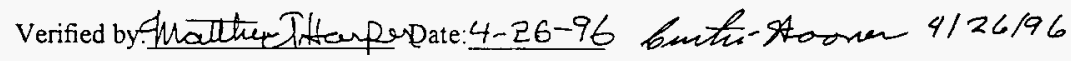

9.3.4 Chiller 118-CH-11-101B will maintain $44^{\circ} \mathrm{F}$ leaving chilled glycol by loading/unloading cylinders and sequencing compressors on and off. This is not a Function of the Andover control System and is internal to chiller $118-\mathrm{CH}-11-101 \mathrm{~B}$.

9.3.5 When the cooling load rises above the capacity of a single chiller and the flow switch FS-653 in the primary-secondary bridge leg detects a flow of approximately 30 GPM recirculation in the primary distribution circuit, the Andover Control System will activate the 118-CH-11-101A system.

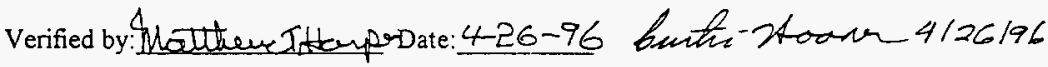

9.3.6 The chilled glycol system will operate with both chillers on-line until the load decreases to approximately $80 \%$ of the capacity of a single chiller. This condition occurs when the venturi/ pressure transducer FE-652 senses approximately 180 GPM recirculation in the secondary circuit. At this time the chiller 118-CH-11-101A will shut down.

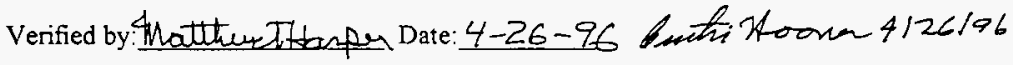

9.3.7 The chiller 118-CH-11-101B system will continue to operate until the outside air temperature drops to $55^{\circ} \mathrm{F}$.

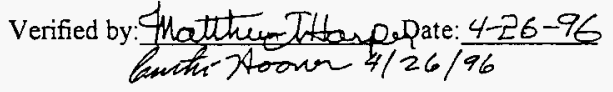

9.3.8 Chiller 118-CH-11-101B system complete.

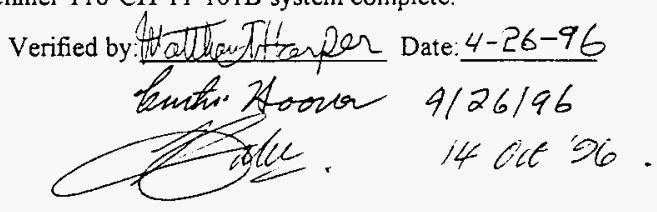




\section{TABLES}

HVAC SYSTEM/PLANT CONTROL SYSTEM INTERFACE SIGNALS

PAGE

SHIPPING/RECEIVING AND NDE/NDA HVAC. $1 \mathrm{~A}, 1 \mathrm{~B}, 1 \mathrm{C}$

ADMINISTRATION AREA $2 \mathrm{~A}, 2 \mathrm{~B}, 2 \mathrm{C}$

ADMINISTRATION (LOCKER ROOMS). $3 \mathrm{~A}, 3 \mathrm{~B}, 3 \mathrm{C}$ COMPUTER AND CONTROL ROOM HVAC $4 \mathrm{~A}, 4 \mathrm{~B}, 4 \mathrm{C}$ PROCESS ZONE I (GLOVEBOX) $6 \mathrm{~A}, 6 \mathrm{~B}, 6 \mathrm{C}$ PROCESS ZONE II (PROCESS AREA) 7A, 7B, 7C

PROCESS AREA SUPPLY AIR $8 \mathrm{~A}, 8 \mathrm{~B}, 8 \mathrm{C}$ CHILLED GLYCOL $9 \mathrm{~A}, 9 \mathrm{~B}, 9 \mathrm{C}$

TABLE SYMBOL AND TYPE KEY:

SYMBOL TYPE
A ANALOG 4-20 MA SIGNAL
B BINARY BIT
DI DISCRETE 3 AMP, 120 VAC DRY CONTACT INPUT TO PCS
V NTEGER VALUE 
NDE-NDA

$1 \mathrm{~A}$

SHIPPING/RECEIVING AND NDE/NDA HVAC

HVAC SYSTEM/PLANT CONTROL SYSTEM INTERFACE SIGNALS

\begin{tabular}{|c|c|c|c|}
\hline TABLE 1A & HVAC DCS TO PCS VIA COMMUNICATION LINK & & VERIFY \\
\hline TAG & DESCRIPTION & TYPE & YES/NO \\
\hline 11-PDISL-624 & RETURN FAN NOT RUNNING OR FAILED, RF-11-101 & B & $y \in s$ \\
\hline $11-\mathrm{TI}-621$ & MIXED AIR TEMPERATURE, AH-11-101 & v & yes \\
\hline 11-PDISH-621 & PRE-FILTER DIRTY, AH-11-101 & $B$ & $Y \in E$ \\
\hline 11-PDISH-622 & FINAL FILTER DIRTY, AH-11-101 & B & YES \\
\hline 11-PDISL-623 & SUPPLY FAN NOT RUNNING OR FAILED, SF-11-101 & B & Y $E S$ \\
\hline $11 . \mathrm{TI}-626$ & SUPPLY AIR TEMPERATURE, AH-11-101 & V & $y \in s$ \\
\hline$|11-T|-627$ & NDESNDA AREA TEMPERATURE, AH-11-101 & $\mathrm{V}$ & YES \\
\hline SF-11-101/S & SHIPPING/RECEIVING AND NDE/NDA SUPPLY FAN RUNNING, SF-11-101 & B & YES \\
\hline RF-11-101/S & SHIPPING/RECEIVING AND NDE/NDA RETURN FAN RUNNING, RF-11-101 & B & YES \\
\hline $11-T I-627 / S P S$ & NDE/NDA AREA CURRENT TEMPERATURE SET POINT, AH-11-101 & $\mathrm{V}$ & YES \\
\hline
\end{tabular}

See Exceporan 11 stef 1.2 .1$.

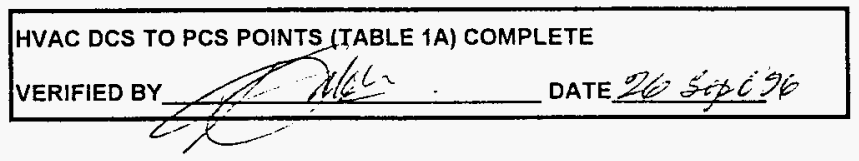


NDE-NDA

1B

SHIPPING/RECEIVING AND NDE/NDA HVAC

HVAC SYSTEM/PLANT CONTROL SYSTEM INTERFACE SIGNALS

\begin{tabular}{|c|c|c|c|}
\hline TABLE 1B & PCS TO HVAC DCS VIA COMMUNICATION LINK & & VERIFY \\
\hline TAG & DESCRIPTION & TYPE & YES/NO \\
\hline AH-11-101/ST & AHU START PULSE, AH-11-101 & B & Yes \\
\hline $\mathrm{AH}-11-101 / \mathrm{SP}$ & AHU STOP PULSE, AH-11-101 & B & Yes \\
\hline $\mathrm{AH}-11-101 / \mathrm{OC}$ & OPERATOR OVER-RIDE TO OCCUPIED CYCLE, AH-11-101 & B & $y \in S$ \\
\hline AH-11-101/UC & OPERATOR OVER-RIDE TO UNOCCUPIED CYCLE, AH-11-101 & B & $y \in S$ \\
\hline $11-T 1-627 / S P$ & NDE/NDA TEMPERATURE SET POINT, AH-11-101 & $\mathrm{v}$ & yes \\
\hline 11-TI-627/EN & ENABLE TEMPERATURE SET POINT PULSE, AH-11-101 & B & YES \\
\hline
\end{tabular}

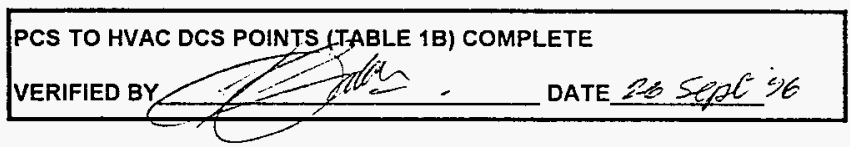


NDE-NDA

SHIPPING/RECEIVING AND NDE/NDA HVAC

HVAC SYSTEM/PLANT CONTROL SYSTEM INTERFACE SIGNALS

\begin{tabular}{|c|c|c|c|}
\hline TABLE 1C & POINTS HARDWIRED TO PCS & & VERIFY \\
\hline TAG & DESCRIPTION & TYPE & YES/NO \\
\hline $11-\times 4-621$ & $\begin{array}{l}\text { SHIPPING/RECEIVING AND NDE/NDA AHU CONTROLLER, C-11-101 } \\
\text { TROUBLE ALARM }\end{array}$ & DI & No \\
\hline
\end{tabular}

POINTS HARDWIRED TO PCS (TABLE 1C) COMPLETE

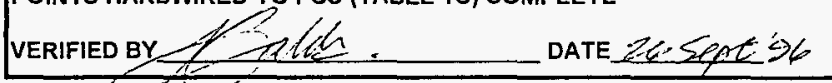


ADMINISTRATION

ADMINISTRATION AREA

HVAC SYSTEM/PLANT CONTROL SYSTEM INTERFACE SIGNALS

\begin{tabular}{|c|c|c|c|}
\hline TABLE 2A & HVAC DCS TO PCS VIA COMMUNICATION LINK & & VERIFY \\
\hline TAG & DESCRIPTION & TYPE & YES NO \\
\hline 11-PDISL-644 & RETURN FAN NOT RUNNING OR FAlLED, RF-11-401 & B & $y e s$ \\
\hline $11-\mathrm{TI}-641$ & OUTSIDE AIR TEMPERATURE, AH-11-401 & V & Yes \\
\hline 11-TI-642 & MIXED AIR TEMERATURE, AH-11.401 & V & $y_{E S}$ \\
\hline 11-PDISH-641 & PRE-FILTER DIRTY, AH-11-401 & $B$ & yes \\
\hline 11-PDISH-642 & FINAL FILTER DIRTY, AH-11-401 & $\mathrm{B}$ & Yes \\
\hline 11-PDISL-643 & SUPPLY FAN NOT RUNNING OR FAILED, AH-11-401 & B & Yes \\
\hline $11-T 1-645$ & SUPPLY AIR TEMPERATURE, AH-11-401 & V & YES \\
\hline $11-\mathrm{F} \mid-643$ & SUPPLY AIR FLOW, AH-11-401 & $v$ & yes \\
\hline 11-PDI-645 & SUPPLY AIR PRESSURE, AH-11-401 & $\mathrm{V}$ & $y \leq 5$ \\
\hline $11-F \mid-642$ & RETURN AIR FLOW, RF-11-401 & V & YES \\
\hline$S F-11-401 / S$ & ADMINISTRATION AREA SUPPLY FAN, SF-11-401 RUNNING & B & YES \\
\hline$R F-11-401 / S$ & ADMINISTRATION AREA RETURN FAN, RF-11-401 RUNNING & B & $y_{e S}$ \\
\hline
\end{tabular}

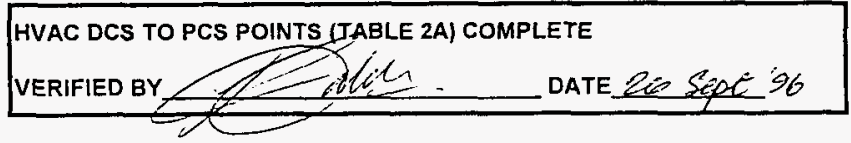




\section{ADMINISTRATION}

2B

ADMINISTRATION AREA

HVAC SYSTEM/PLANT CONTROL SYSTEM INTERFACE SIGNALS

\begin{tabular}{|c|c|c|c|}
\hline TABLE 2B & \multicolumn{1}{|c|}{ PCS TO HVAC DCS VIA COMMUNICATION LINK } & VERIFY \\
\hline TAG & DESCRIPTION & TYPE & YES/NO \\
\hline AH-11-401/ST & AHU START PULSE, AH-11-401 & B & YES \\
\hline AH-11-401/SP & AHU STOP PULSE, AH-11-401 & B & YES \\
\hline AH-11-401/OC & OPERATOR OVER-RIDE TO OCCUPIED CYCLE, AH-11-401 & B & YES \\
\hline AH-11-401/UC & OPERATOR OVER-RIDE TO UNOCCUPIED CYCLE, AH-11-401 & B & YES \\
\hline
\end{tabular}

SEE EXCEPTCN \& SYEP 2.2.1

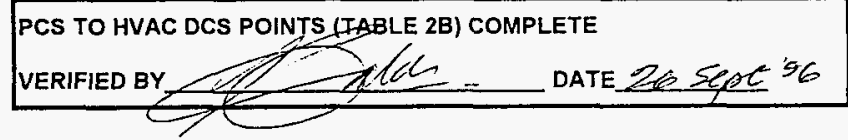


ADMINISTRATION

$2 \mathrm{C}$

ADMINISTRATION AREA

HVAC SYSTEM/PLANT CONTROL SYSTEM INTERFACE SIGNALS

\begin{tabular}{|c|c|c|c|}
\hline TABLE 2C & POINTS HARDWIRED TO PCS & VERIFY \\
\hline TAG & DESCRIPTION & TYPE & YES/NO \\
\hline 11 -XA-641 & ADMINISTRATION AREA CONTROLLER, C-11-401 TROUBLE ALARM & DI & $\gamma \in S$ \\
\hline
\end{tabular}

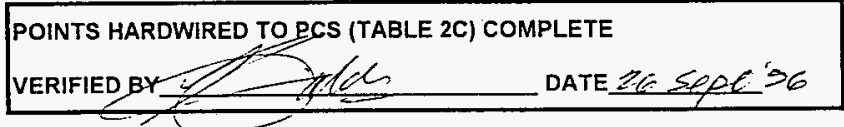




\section{LOCKER ROOMS}

ADMINISTRATION (LOCKER ROOMS)

HVAC SYSTEM/PLANT CONTROL SYSTEM INTERFACE SIGNALS

\begin{tabular}{|c|c|c|c|}
\hline TABLE 3A & HVAC DCS TO PCS VIA COMMUNICATION LINK & & VERIFY \\
\hline TAG & DESCRIPTION & TYPE & YES/NO \\
\hline $11-\mathrm{Tl}-665$ & SUPPLY AIR TEMPERATURE, AH-11-301 & $v$ & 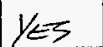 \\
\hline 11-PDISH-661 & PRE-FILTER DIRTY, AH-11-301 & B & $y / 25$ \\
\hline 11-PDISH-662 & FINAL FILTER DIRTY, AH-11-301 & B & $1 / \leq 5$ \\
\hline 11-PDISL-663 & SUPPLY FAN NOT RUNNING OR FAILED, SF-11-301 & B & $y / \infty$ \\
\hline $11-T i-668$ & LOCKER ROOM AREA TEMPERATURE, AH-11-301 & V & $y / 5$ \\
\hline $11-T \mid-668 / S P S$ & CURRENT LOCKER ROOM AREA TEMPERATURE SET POINT, AH-11-301 & $\mathrm{v}$ & Ies \\
\hline$E F \cdot 11-301 / S$ & EXHAUST FAN RUNNING & B & $y \in S$ \\
\hline $\mathrm{AH}-11-301 / \mathrm{S}$ & ADMINISTRATION LOCKER ROOM AREA AHU RUNNING & B & $y_{E S}$ \\
\hline
\end{tabular}

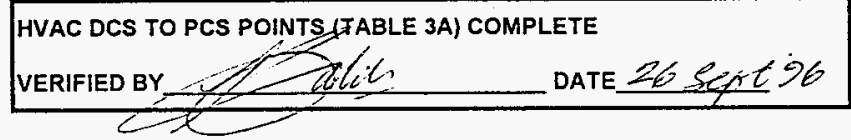




\section{LOCKER ROOMS}

ADMINISTRATION (LOCKER ROOMS)

HVAC SYSTEM/PLANT CONTROL SYSTEM INTERFACE SIGNALS

\begin{tabular}{|l|l|c|c|}
\hline TABLE 3B & \multicolumn{1}{|c|}{ PCS TO HVAC DCS VIA COMMUNICATION LINK } & VERIFY \\
\hline TAG & \multicolumn{1}{|c|}{ DESCRIPTION } & TYPE & YES/NO \\
\hline AH-11-301/ST & AHU START PULSE, AH-11-301 & $\mathrm{B}$ & YES \\
\hline AH-11-301/SP & AHU STOP PULSE, AH-11-301 & $\mathrm{B}$ & YES \\
\hline AH-11-301/OC & OPERATOR OVER-RIDE TO OCCUPIED CYCLE, AH-11-301 & $\mathrm{B}$ & \\
\hline AH-11-301/UC & OPERATOR OVER-RIDE TO UNOCCUPIED CYCLE, AH-11-301 & $\mathrm{B}$ & \\
\hline 11-TI-668/SP & LOCKER ROOM AREA TEMPERATURE SET POINT, AH-11-301 & $\mathrm{V}$ & Y/ES \\
\hline
\end{tabular}

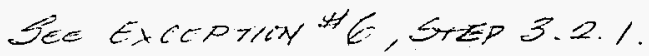

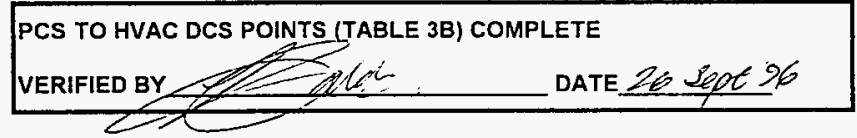




\section{LOCKER ROOMS}

ADMINISTRATION (LOCKER ROOMS)

HVAC SYSTEM/PLANT CONTROL SYSTEM INTERFACE SIGNALS

\begin{tabular}{|c|c|c|c|}
\hline TABLE 3C & POINTS HARDWIRED TO PCS & & VERIFY \\
\hline TAG & DESCRIPTION & TYPE & YES/NO \\
\hline $11-$ XA-661 & $\begin{array}{l}\text { ADMINISTRATION AREA LOCKER ROOMS AHU CONTROLLER, C-11-301 } \\
\text { TROUBLE ALARM }\end{array}$ & DI & YES \\
\hline
\end{tabular}

POINTS HARDWIRED TO PCS, (TABLE 3C) COMPLETE

VERIFIED By SPATE ze seoc SC 


\section{COMPUTER ROOM}

COMPUTER AND CONTROL ROOM HVAC

HVAC SYSTEMIPLANT CONTROL SYSTEM INTERFACE SIGNALS

\begin{tabular}{|c|c|c|c|}
\hline TABLE 4A & HVAC DCS TO PCS VIA COMMUNICATION LINK & & VERIFY \\
\hline TAG & DESCRIPTION & TYPE & YES/NO \\
\hline 11-PDISL-633A & SUPPLY FAN NOT RUNNING OR FAILED, SF-11-501A & $\mathrm{B}$ & $y_{E S}$ \\
\hline $11-T \mid-635 A$ & MIXED AIR TEMPERATURE, AH-11-501A & V & $y_{E S}$ \\
\hline 11-PDISH-631A & PRE-FILTER DIRTY, AH-11-501A & B & $Y \in S$ \\
\hline 11-PDISH-632A & FINAL FILTER DIRTY, AH-11-501A & B & YES \\
\hline $11-\mathrm{TI}-637 \mathrm{~A}$ & SUPPLY AIR TEMPERATURE, AH-11-501A & V & YEs \\
\hline $11-\mathrm{MI}-632 \mathrm{~A}$ & CONTROL ROOM HUMIDITY, AH-11-501A & V & YES \\
\hline 11-MI-632AVSPS & CURRENT CONTROL ROOM HUMIDITY SET POINT, AH-11-501A & V & $Y / E S$ \\
\hline $11-\mathrm{TI}-632 \mathrm{~A}$ & CONTROL ROOM TEMPERATURE, AH-11-501A & $\mathrm{V}$ & $Y / E 5$ \\
\hline $11-\mathrm{TI}-632 \mathrm{~A} / \mathrm{SPS}$ & CURRENT CONTROL ROOM TEMPERATURE SET POINT, AH-11-501A & V & Yes \\
\hline $\mathrm{SF}-11-501 \mathrm{~A} / \mathrm{S}$ & SUPPLY FAN, SF-11-501A RUNNING & B & $Y \in E$ \\
\hline 11-PDISL-633B & SUPPLY FAN NOT RUNNING OR FAILED, SF-11-501B & B & Yes \\
\hline $11-\mathrm{TI}-635 \mathrm{~B}$ & MIXED AIR TEMPERATURE, AH-11-501B & V & $Y \in=5$ \\
\hline 11-PDISH-631B & PRE-FILTER DIRTY, AH-11-501B & B & YES \\
\hline 11-PDISH-632B & FINAL FILTER DIRTY, AH-11-501B & B & Yes \\
\hline $41-T 1-637 B$ & SUPPLY AIR TEMPERATURE, AH-11-501B & v & Yes \\
\hline 11-MI-632B & CONTROL ROOM HUMIDITY, AH-11-501B & V & YES \\
\hline 11-MI-632B/SPS & CURRENT CONTROL ROOM HUMIDITY SET POINT, AH-11-501B & V & Yes \\
\hline $11-T \mid-632 B$ & CONTROL ROOM TEMPERATURE, AH-11-501B & V & Yes \\
\hline $11-\mathrm{TI}-632 \mathrm{~B} / \mathrm{SPS}$ & CURRENT CONTROL ROOM TEMPERATURE SET POINT, AH-11-501B & 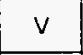 & $1 / E S$ \\
\hline SF-11-501B/S & SUPPLY FAN, SF-11-501B RUNNING & $\mathbf{B}$ & Yes \\
\hline
\end{tabular}

HVAC DCS TO PCS POINTS (TABLE 4A) COMPLETE

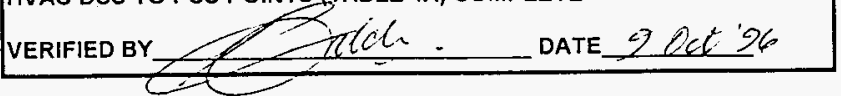




\section{COMPUTER ROOM}

COMPUTER AND CONTROL ROOM HVAC

HVAC SYSTEM/PLANT CONTROL SYSTEM INTERFACE SIGNALS

\begin{tabular}{|c|c|c|c|}
\hline TABLE 4B & PCS TO HVAC DCS VIA COMMUNICATION LINK & & VERIFY \\
\hline TAG & DESCRIPTION & TYPE & YES/NO \\
\hline $\mathrm{AH}-11-501 \mathrm{~A} / \mathrm{ST}$ & AHU START PULSE, AH-11-501A & $\mathrm{B}$ & $1 \in S$ \\
\hline AH-11-501A/SP & AHU STOP PULSE, AH-11-501A & B & Yes \\
\hline $11-T I-632 A / S P$ & CONTROL ROOM TEMPERATURE SET POINT, AH-11-501A & $\mathrm{V}$ & $y \in=5$ \\
\hline $11-T I-632 A / E N$ & ENABLE TEMPERATURE SET POINT PULSE, AH-11-501A & B & $Y \in S$ \\
\hline $11-\mathrm{MI}-632 \mathrm{~A} / \mathrm{SP}$ & CONTROL ROOM HUMIDITY SET POINT, AH-19-501A & $\mathrm{V}$ & Yes \\
\hline 11-MI-632A/EN & ENABLE HUMIDITY SET POINT PULSE, AH-11-501A & B & $1 / 05$ \\
\hline $\mathrm{AH}-11-501 \mathrm{~B} / \mathrm{ST}$ & AHU START PULSE, AH-11-5018 & B & $y \in S$ \\
\hline $\mathrm{AH}-11-501 \mathrm{~B} / \mathrm{SP}$ & AHU STOP PULSE, AH-11-501B & B & $y \in S$ \\
\hline $11-\mathrm{TI}-632 \mathrm{~B} / \mathrm{SP}$ & CONTROL ROOM TEMPERATURE SET POINT, AH-11-501B & V & Yes \\
\hline 11-T1-632B/EN & ENABLE TEMPERATURE SET POINT PULSE, AH-11-501B & B & YES \\
\hline $11-\mathrm{M} 1-632 \mathrm{~B} / \mathrm{SP}$ & CONTROL ROOM HUMIDITY SET POINT, AH-11-501B & $\mathrm{V}$ & $Y_{E S}$ \\
\hline 11-MI-632B/EN & ENABLE HUMIDITY SET POINT PULSE, AH-11-501B & B & $y / t=5$ \\
\hline
\end{tabular}

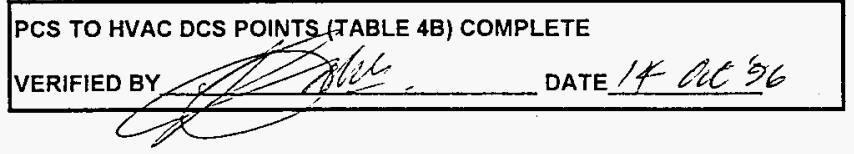


HNF-SD-W026-ATR-016, Rev. 0 Page 57

COMPUTER ROOM

$4 C$

COMPUTER AND CONTROL ROOM HVAC

HVAC SYSTEM/PLANT CONTROL SYSTEM INTERFACE SIGNALS

\begin{tabular}{|c|c|c|c|}
\hline TABLE 4C & \multicolumn{1}{|c|}{ POINTS HARDWIRED TO PCS } & & VERIFY \\
\hline TAG & \multicolumn{1}{|c|}{ DESCRIPTION } & TYPE & YES/NO \\
\hline $11-X A-631 \mathrm{~A}$ & $\begin{array}{l}\text { COMPUTER AND CONTROL ROOM AHU A, CONTROLLER C-11-501A } \\
\text { TROUBLE ALARM }\end{array}$ & $\mathrm{DI}$ & $Y_{E S}$ \\
\hline 11-XA-631B & $\begin{array}{l}\text { COMPUTER AND CONTROL ROOM AHU B, CONTROLLER C-11-501B } \\
\text { TROUBLE ALARM }\end{array}$ & $\mathrm{DI}$ & $1 / E 5$ \\
\hline
\end{tabular}

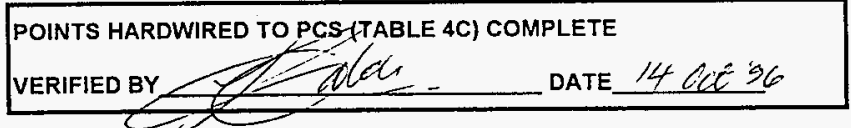


PROCESS ZONE I

PROCESS ZONE I (GLOVEBOX)

HVAC SYSTEM/PLANT CONTROL SYSTEM INTERFACE SIGNALS

\begin{tabular}{|c|c|c|c|}
\hline TABLE 6A & HVAC DCS TO PCS VIA COMMUNICATION LINK & & VERIFY \\
\hline TAG & DESCRIPTION & TYPE & YES/NO \\
\hline 11-PDI-392 & LLW RESTRICTED WASTE GLOVEBOX DIFFERENTIAL PRESSURE. & $v$ & \\
\hline $11-P D \mid-372$ & TRU RESTRICTED WASTE GLOVEBOX DIFFERENTIAL PRESSURE & V & \\
\hline 11-PDI-317 & LLW GLOVEBOX DIFFERENTIAL PRESSURE & V & \\
\hline 11-PDI-315 & TRU GLOVEBOX DIFFERENTIAL PRESSURE & 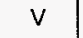 & \\
\hline $11-F \mid-391$ & LLW RESTRICTED WASTE GLOVEBOX AIRFLOW & V & \\
\hline $11-F \mid-371$ & TRU RESTRICTED WASTE GLOVEBOX AIRFLOW & V & \\
\hline $11-F \mid-316$ & LLW GLOVEBOX AIRFLOW & $\mathrm{V}$ & \\
\hline $11-F !-314$ & TRU GLOVEBOX AIRFLOW & V & \\
\hline 11-PDI-611A & EXHAUST FILTER - TRAIN A DIFFERENTIAL PRESSURE, FT-11-201A & V & \\
\hline 11-PDISH-611A & PRE-FILTER DIRTY - TRAIN A, FT-11-201A & B & \\
\hline 11-PDISH-613A & FIRST HEPA FILTER DIRTY - TRAIN A, FT-11-201A & B & \\
\hline 14-PDISH-615A & SECOND HEPA FILTER DIRTY - TRAIN A, FT-11-201A & B & \\
\hline 11-PDISL-617A & EXHAUST FAN NOT RUNNING OR FAILED - TRAIN A, EF-11-201A & B & \\
\hline 11-FI-617A & EXHAUST FLOW - TRAIN A, EF-11-201A & V & \\
\hline $11-$ FI-617AVSPS & CURRENT EXHAUST FLOW SET POINT - TRAIN A, EF-11-201A & V & \\
\hline EF-11-201AVS & EXHAUST FAN, EF-11-201A RUNNING & B & \\
\hline 11-PDI-611B & EXHAUST FILTER - TRAIN B DIFFERENTIAL PRESSURE, FT-11-201B & V & \\
\hline 11-PDISH-611B & PRE-FILTER DIRTY - TRAIN B, FT-11-201B & B & \\
\hline 11-PDISH-613B & FIRST HEPA FILTER DIRTY - TRAIN B, FT-11-201B & $\mathrm{B}$ & \\
\hline 11-PDISH-615B & SECOND HEPA FILTER DIRTY - TRAIN B, FT-11-201B & B & \\
\hline 11-PDISL-617B & EXHAUST FAN NOT RUNNING OR FAILED - TRAIN B, EF-11-201B & $B$ & \\
\hline $11-\mathrm{Fl}-617 \mathrm{~B}$ & EXHAUST FLOW - TRAIN B, EF-11-201B & V & \\
\hline $11-\mathrm{FI}-617 \mathrm{~B} / \mathrm{SPS}$ & CURRENT EXHAUST FLOW SET POINT - TRAIN B, EF-11-201B & 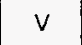 & \\
\hline$E F-11-201 B / S$ & EXHAUST FAN, EF-11-201B RUNNING & B & \\
\hline
\end{tabular}

\begin{tabular}{l} 
HVAC DCS TO PCS POINTS (TABLE 6A) COMPLETE \\
VERIFIED BY \\
\hline
\end{tabular} 
PROCESS ZONE 1

PROCESS ZONE I (GLOVEBOX)

HVAC SYSTEM/PLANT CONTROL SYSTEM INTERFACE SIGNALS

\begin{tabular}{|c|l|c|c|}
\hline TABLE 6B & \multicolumn{1}{|c|}{ PCS TO HVAC DCS VIA COMMUNICATION LINK } & VERIFY \\
\hline TAG & \multicolumn{1}{|c|}{ DESCRIPTION } & TYPE & YES/NO \\
\hline FT-11-201AVT & EXHAUST FILTER TRAIN A START PULSE, EF-11-201A & $\mathrm{B}$ & \\
\hline FT-11-201A/SP & EXHAUST FILTER TRAIN A STOP PULSE, EF-11-201A & $\mathrm{B}$ & \\
\hline $11-F I-617 \mathrm{~A} / \mathrm{SP}$ & EXHAUST FLOW SET POINT - TRAIN A, EF-11-201A & $\mathrm{V}$ & \\
\hline $11-F 1-617 \mathrm{~A} / \mathrm{A} N$ & ENABLE EXHAUST FLOW SET POINT PULSE - TRAIN A, EF-11-201A & $\mathrm{B}$ & \\
\hline FT-11-201B/ST & EXHAUST FILTER TRAIN B START PULSE, EF-11-201B & $\mathrm{B}$ & \\
\hline FT-11-201B/SP & EXHAUST FILTER TRAIN B STOP PULSE, EF-11-201B & $\mathrm{B}$ & \\
\hline $11-F I-617 \mathrm{~B} / \mathrm{SP}$ & EXHAUST FLOW SET POINT - TRAIN B, EF-11-201B & $\mathrm{V}$ & \\
\hline $11-F I-617 \mathrm{~B} / E N$ & ENABLE EXHAUST FLOW SET POINT PULSE - TRAIN B, EF-11-201B & $\mathrm{B}$ & \\
\hline
\end{tabular}

PCS TO HVAC DCS POINTS (TABLE 6B) COMPLETE

VERIFIED BY DATE 
HNF-SD-W026-ATR-016, Rev. 0 Page 60

PROCESS ZONE I

PROCESS ZONE I (GLOVEBOX)

HVAC SYSTEM/PLANT CONTROL SYSTEM INTERFACE SIGNALS

\begin{tabular}{|c|c|c|c|}
\hline TABLE 6C & POINTS HARDWIRED TO PCS & VERIFY \\
\hline TAG & DESCRIPTION & TYPE & YES/NO \\
\hline $11-X A-611 \mathrm{~A}$ & EXHAUST FILTER TRAIN CONTROLLER C-11-201A TROUBLE ALARM & DI & \\
\hline $11-X A-611 \mathrm{~B}$ & EXHAUST FILTER TRAIN CONTROLLER C-11-201B TROUBLE ALARM & DI & \\
\hline
\end{tabular}

POINTS HARDWIRED TO PCS (TABLE 6C) COMPLETE VERIFIED BY DATE 
PROCESS ZONE ॥

PROCESS ZONE II (PROCESS AREA)

HVAC SYSTEM/PLANT CONTROL SYSTEM INTERFACE SIGNALS

\begin{tabular}{|c|c|c|c|}
\hline TABLE 7A & HVAC DCS TO PCS VIA COMMUNICATION LINK & & VERIFY \\
\hline TAG & DESCRIPTION & TYPE & YES/NO \\
\hline 11-PDISH-612A & PRE-FILTER DIRTY, FILTER TRAIN A, FT-11-202A & $\mathrm{B}$ & \\
\hline 11-PDISH-614A & FIRST HEPA FILTER DIRTY, FILTER TRAIN A, FT-11-202A & $\mathrm{B}$ & \\
\hline 11-PDISH-616A & SECOND HEPA FILTER DIRTY, FILTER TRAIN A, FT-11-202A & $B$ & \\
\hline $11-T \mid-618 A$ & EXHAUST AIR TEMPERATURE, FILTER TRAIN A, FT-11-202A & $\mathrm{V}$ & \\
\hline 11-PDISL-618A & EXHAUST FAN NOT RUNNING OR FAILED, EF-11-202A & B & \\
\hline $11-F \mid-618 A$ & EXHAUST AIR FLOW, EF-11-202A & V & \\
\hline $11-\mathrm{Fl}-618$ ANSPS & CURRENT EXHAUST AIR FLOW SET POINT, EF-11-202A & V & \\
\hline FT-11-202A/S & EXHAUST FAN RUNNING, EF-11-202A & $B$ & \\
\hline 11-PDISH-612B & PRE-FILTER DIRTY, FILTER TRAIN B, FT-11-202B & B & \\
\hline 11-PDISH-614B & FIRST HEPA FHLTER DIRTY, FILTER TRAIN B, FT-11-202B & B & \\
\hline 11-PDISH-616B & SECOND HEPA FILTER DIRTY, FILTER TRAIN B, FT-11-202B & $\mathrm{B}$ & \\
\hline $11-\mathrm{TI}-618 \mathrm{~B}$ & EXHAUST AIR TEMPERATURE, FILTER TRAIN B, FT-11-202B & V & \\
\hline 11-POISL-618B & EXHAUST FAN NOT RUNNING OR FAILED, EF-11-202B & B & \\
\hline $11-\mathrm{FI}-618 \mathrm{~B}$ & EXHAUST AIR FLOW, EF-11-202B & $\mathrm{V}$ & \\
\hline $11-\mathrm{FI}-618 \mathrm{~B} / \mathrm{SPS}$ & CURRENT EXHAUST AIR FLOW SET POINT, EF-11-202B & V & \\
\hline$F T-11-202 B / S$ & EXHAUST FAN RUNNING, EF-11-202B & B & \\
\hline $11-Z S O-608$ & ZONE II EXHAUST FIRE DAMPER OPEN & B & \\
\hline $11-Z S C-608$ & ZONE II EXHAUST FIRE DAMPER CLOSED & B & \\
\hline
\end{tabular}

\begin{tabular}{l} 
HVAC DCS TO PCS POINTS (TABLE TA) COMPLETE \\
VERIFIED BY DATE \\
\hline
\end{tabular}


PROCESS ZONE II

PROCESS ZONE $\|$ (PROCESS AREA)

HVAC SYSTEM/PLANT CONTROL SYSTEM INTERFACE SIGNALS

\begin{tabular}{|c|l|c|c|}
\hline TABLE 7B & \multicolumn{1}{|c|}{ PCS TO HVAC DCS VIA COMMUNICATION LINK } & VERIFY \\
\hline TAG & \multicolumn{1}{|c|}{ DESCRIPTION } & TYPE & YES/NO \\
\hline FT-11-202AVT & EXHAUST FILTER TRAIN A START PULSE, FT-11-202A & $\mathrm{B}$ & \\
\hline FT-11-202A/SP & EXHAUST FILTER TRAIN A STOP PULSE, FT-11-202A & $\mathrm{B}$ & \\
\hline 11-FI-618AVSP & EXHAUST AIR FLOW SET POINT, EF-11-202A & $\mathrm{B}$ & \\
\hline 11-FI-618AJEN & ENABLE EXHAUST AIR FLOW SET POINT PULSE, EF-11-202A & $\mathrm{B}$ & \\
\hline FT-11-202B/ST & EXHAUST FILTER TRAIN B START PULSE, FT-11-202B & $\mathrm{B}$ & \\
\hline FT-11-202B/SP & EXHAUST FILTER TRAIN B STOP PULSE, FT-11-202B & $\mathrm{B}$ & \\
\hline 11-FI-618B/SP & EXHAUST AIR FLOW SET POINT, EF-11-202B & $\mathrm{B}$ & \\
\hline 11-FI-618B/EN & ENABLE EXHAUST AIR FLOW SET POINT PULSE, EF-11-202B & $\mathrm{B}$ & \\
\hline
\end{tabular}

PCS TO HVAC DCS POINTS (TABLE 7B) COMPLETE

VERIFIED BY DATE 
PROCESS ZONE ॥

PROCESS ZONE II (PROCESS AREA)

HVAC SYSTEM/PLANT CONTROL SYSTEM INTERFACE SIGNALS

\begin{tabular}{|c|l|c|c|}
\hline TABLE 7C & \multicolumn{1}{|c|}{ POINTS HARDWIRED TO PCS } & VERIFY \\
\hline TAG & \multicolumn{1}{|c|}{ DESCRIPTION } & TYPE & YES/NO \\
\hline 11-PDIT-601 & $\begin{array}{l}\text { NON-CONFINEMENT / ZONE II PROCESS HVAC DIFFERENTIAL } \\
\text { PRESSURE }\end{array}$ & A & \\
\hline $11-P D I T-602$ & NON-CONFINEMENT / ZONE II PROCESS DIFFERENTIAL PRESSURE & A & \\
\hline 11-PDIT-603 & ZONE II PROCESS HVAC / ZONE II PROCESS DIFFERENTIAL PRESSURE & \\
\hline 11-PDIT-606 & NON-CONFINEMENT / ATMOSPHERE DIFFERENTIAL PRESSURE & A & \\
\hline 11-PDIT-607 & ATMOSPHERE / ZONE II PROCESS DIFFERENTIAL PRESSURE & A & \\
\hline 11-XA-612A & EXHAUST FILTER TRAIN CONTROLLER, C-11-202A TROUBLE ALARM & DI & \\
\hline 11-XA-612B & EXHAUST FILTER TRAIN CONTROLLER, C-11-202B TROUBLE ALARM & DI & \\
\hline
\end{tabular}

POINTS HARDWIRED TO PCS (TABLE 7C) COMPLETE DATE 
PROCESS SUPPLY AIR

PROCESS AREA SUPPLY AIR

HVAC SYSTEM/PLANT CONTROL SYSTEM INTERFACE SIGNALS

\begin{tabular}{|c|c|c|c|}
\hline TABLE BA & HVAC DCS TO PCS VIA COMMUNICATION LINK & & VERIFY \\
\hline TAG & DESCRIPTION & TYPE & YES/NO \\
\hline 11-PDISH-601A & PRE-FILTER DIRTY, AH-11-201A & $\mathrm{B}$ & \\
\hline 11-PDISH-602A & FINAL FILTER DIRTY, AH-11-201A & $\mathrm{B}$ & \\
\hline $11-\mathrm{Tl}-601 \mathrm{~A}$ & OUTSIDE AIR TEMPERATURE, AH-11-201A & V & \\
\hline $11-T)-605 \mathrm{~A}$ & SUPPLY AIR TEMPERATURE, AH-11-201A & V & \\
\hline 11-PDISL-603A & SUPPLY FAN NOT RUNNING OR FAILED, SF-11-201A & B & \\
\hline $11-F !-603 A$ & SUPPLY AIR FLOW, AH-11-201A & $\mathrm{v}$ & \\
\hline 11-FI-603A/SPS & CURRENT SUPPLY AIR FLOW SET POINT, AH-11-201A & $\checkmark$ & \\
\hline $11-T 1-609 A$ & PROCESS AREA TEMPERATURE, AH-11-201A & V & \\
\hline $11-T 1-609 A / S P S$ & CURRENT PROCESS AREA TEMPERATURE SET POINT, AH-11-201A & V & \\
\hline $\mathrm{AH}-11-201 \mathrm{~A} / \mathrm{S}$ & PROCESS AREA AHU, AH-11-201A, RUNNING & B & \\
\hline 11-PDISH-601B & PRE-FILTER DIRTY, AH-11-201B & $\mathrm{B}$ & \\
\hline 11-PDISH-602B & FINAL FILTER DIRTY, AH-11-201B & B & \\
\hline $11-\mathrm{TI}-601 \mathrm{~B}$ & OUTSIDE AIR TEMPERATURE, AH-11-201B & V & \\
\hline $11-T \mid-605 B$ & SUPPLY AIR TEMPERATURE, AH-11-201B & V & \\
\hline 11-PDISL-6038 & SUPPLY FAN NOT RUNNING OR FAILED, SF-11-201B & B & \\
\hline $11-\mathrm{FI}-603 \mathrm{~B}$ & SUPPLY AIR FLOW, AH-11-201B & V & \\
\hline $11-\mathrm{Fl}-603 \mathrm{~B} / \mathrm{SPS}$ & CURRENT SUPPLY AIR FLOW SET POINT, AH-11-201B & $\checkmark$ & \\
\hline $11-T 1-609 B$ & PROCESS AREA TEMPERATURE, AH-11-201B & V & \\
\hline$|11-T|-609 B / S P S$ & CURRENT PROCESS AREA TEMPERATURE SET POINT, AH-11-201B & V & \\
\hline$A H-11-201 B / S$ & PROCESS AREA AHU, AH-11-201B, RUNNING & B & \\
\hline
\end{tabular}

HVAC DCS TO PCS POINTS (TABLE 8A) COMPLETE

VERIFIED BY DATE 
HNF-SD-W026-ATR-016, Rev. 0 Pag̀e 65

\section{PROCESS SUPPLY AIR}

PROCESS AREA SUPPLY AIR

HVAC SYSTEM/PLANT CONTROL SYSTEM INTERFACE SIGNALS

\begin{tabular}{|c|c|c|c|}
\hline TABLE 8B & PCS TO HVAC DCS VIA COMMUNICATION LINK & & VERIFY \\
\hline TAG & DESCRIPTION & TYPE & YES/NO \\
\hline AH-11-201AVST & PROCESS AREA AHU START PULSE, AH-11-201A & B & \\
\hline AH-11-20tAVSP & PROCESS AREA AHU STOP PULSE, AH-11-201A & B & \\
\hline $11-\mathrm{FI}-603 \mathrm{~A} / \mathrm{SP}$ & SUPPLY AIR FLOW SET POINT, AH-11-201A & V & \\
\hline 11-Fl-603A/EN & ENABLE SUPPLY AIR FLOW SET POINT PULSE, AH-11-201A & $\mathrm{B}$ & \\
\hline 11-TI-609AVSP & PROCESS AREA TEMPERATURE SET POINT, AH-11-201A & V & \\
\hline 11-TI-609AEN & ENABLE TEMPERATURE SET POINT PULSE, AH-11-201A & $B$ & \\
\hline $\mathrm{AH}-11-201 \mathrm{~B} / \mathrm{ST}$ & PROCESS AREA AHU START PULSE, AH-11-201B & B & \\
\hline $\mathrm{AH}-11-201 \mathrm{~B} / \mathrm{SP}$ & PROCESS AREA AHU STOP PULSE, AH-11-201B & $\mathrm{B}$ & \\
\hline 19-Fl-603B/SP & SUPPLY AIR FLOW SET POINT, AH-11-201B & V & \\
\hline $11-\mathrm{F} !-603 \mathrm{~B} / \mathrm{EN}$ & ENABLE SUPPLY AIR FLOW SET POINT PULSE, AH-11-201B & B & \\
\hline $11-T \mid-609 B / S P$ & PROCESS AREA TEMPERATURE SET POINT, AH-11-201B & V & \\
\hline 11-TI-609B/EN & ENABLE TEMPERATURE SET POINT PULSE, AH-11-201B & $\mathrm{B}$ & \\
\hline
\end{tabular}

PCS TO HVAC DCS POINTS (TABLE 8B) COMPLETE

VERIFIED BY DATE 
PROCESS SUPPLY AIR

PROCESS AREA SUPPLY AIR

HVAC SYSTEM/PLANT CONTROL SYSTEM INTERFACE SIGNALS

\begin{tabular}{|c|l|c|c|}
\hline TABLE 8C & \multicolumn{1}{|c|}{ POINTS HARDWIRED TO PCS } & VERIFY \\
\hline TAG & \multicolumn{1}{|c|}{ DESCRIPTION } & TYPE & YES/NO \\
\hline $11-$ XA-601A & PROCESS AREA AHU CONTROLLER, C-11-201A, TROUBLE ALARM & DI & \\
\hline $11-$ XA-601B & PROCESS AREA AHU CONTROLLER, C-11-201B, TROUBLE ALARM & DI & \\
\hline $11-Z S O-604$ & COMMON SUPPLY AIR DAMPER OPEN & DI & \\
\hline $11-Z S C-604$ & COMMON SUPPLY AIR DAMPER CLOSED & DI & \\
\hline
\end{tabular}

POINTS HARDWIRED TO PCS (TABLE 8C) COMPLETE

VERIFIED BY DATE 


\section{CHILLERS}

CHILLED GLYCOL

HVAC SYSTEM/PLANT CONTROL SYSTEM INTERFACE SIGNALS

\begin{tabular}{|l|l|c|c|}
\hline TABLE 9A & \multicolumn{1}{|c|}{ HVAC DCS TO PCS VIA COMMUNICATION LINK } & VERIFY \\
\hline TAG & \multicolumn{1}{|c|}{ DESCRIPTION } & TYPE & YES/NO \\
\hline 11-FI-652 & CHILLED GLYCOL PRIMARY-SECONDARY BRIDGE FLOW & V & YES \\
\hline P-11-101AUS & CHILLED GLYCOL DISTRIBUTION PUMP P-11-101A RUNNING & B & Y/ES \\
\hline P-11-101B/S & CHILLED GLYCOL DISTRIBUTION PUMP P-11-101B RUNNING & B & YES \\
\hline P-11-102AVS & CHILLER CIRCULATION PUMP P-11-102A RUNNING & B & $1 / E S$ \\
\hline P-11-102B/S & CHILLER CIRCULATION PUMP P-11-102B RUNNING & B & YZS \\
\hline
\end{tabular}

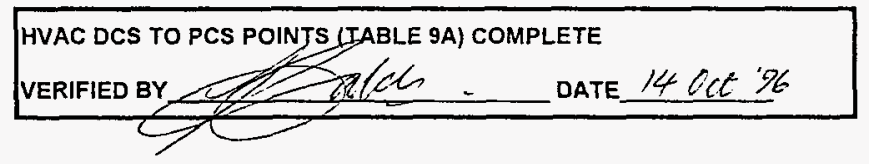


CHILLERS

CHILLED GLYCOL

HVAC SYSTEM/PLANT CONTROL SYSTEM INTERFACE SIGNALS

\begin{tabular}{|l|l|c|c|}
\hline TABLE 9B & \multicolumn{1}{|c|}{ PCS TO HVAC DCS VIA COMMUNICATION LINK } & & VERIFY \\
\hline TAG & \multicolumn{1}{|c|}{ DESCRIPTION } & TYPE & YES/NO \\
\hline P-11-101A/ST & CHILLED GLYCOL DISTRIBUTION PUMP P-11-101A START PULSE & B & Y'ES \\
\hline P-11-101A/SP & CHILLED GLYCOL DISTRIBUTION PUMP P-11-101A STOP PULSE & B & V/ES \\
\hline P-11-101B/ST & CHILLED GLYCOL DISTRIBUTION PUMP P-11-101B START PULSE & B & V/ES \\
\hline P-11-101B/SP & CHILLED GLYCOL DISTRIBUTION PUMP P-11-101B STOP PULSE & B & YES \\
\hline P-11-102A/ST & CHILLER CIRCULATION PUMP P-11-102A START PULSE & B & YES \\
\hline P-11-102A/SP & CHILLER CIRCULATION PUMP P-11-102A STOP PULSE & B & YES \\
\hline P-11-102B/ST & CHILLER CIRCULATION PUMP P-11-102B START PULSE & B & YES \\
\hline P-11-102B/SP & CHILLER CIRCULATION PUMP P-11-102B STOP PULSE & B & YES \\
\hline
\end{tabular}

SEe Exceptan 5 , STeP 9.1.0.

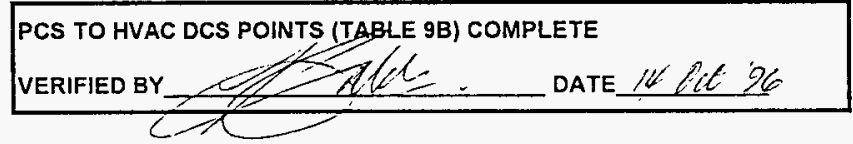




\section{CHILLERS}

CHILLED GLYCOL

HVAC SYSTEM/PLANT CONTROL SYSTEM INTERFACE SIGNALS

\begin{tabular}{|c|c|c|c|}
\hline TABLE 9C & \multicolumn{1}{|c|}{ POINTS HARDWIRED TO PCS } & VERIFY \\
\hline TAG & DESCRIPTION & TYPE & YES/NO \\
\hline $11-X A-651$ & CHILLED GLYCOL SYSTEM CONTROLLER, C-11-101 TROUBLE ALARM & DI & $Y_{\text {ES }}$ \\
\hline $11-$ TIT-652 & CHILLED GLYCOL TEMPERATURE & A & YES \\
\hline
\end{tabular}

POINTS HARDWIRED TO PCS (IABLE 9C) COMPLETE

VERIFIED BY DATE 14 ECL 96 